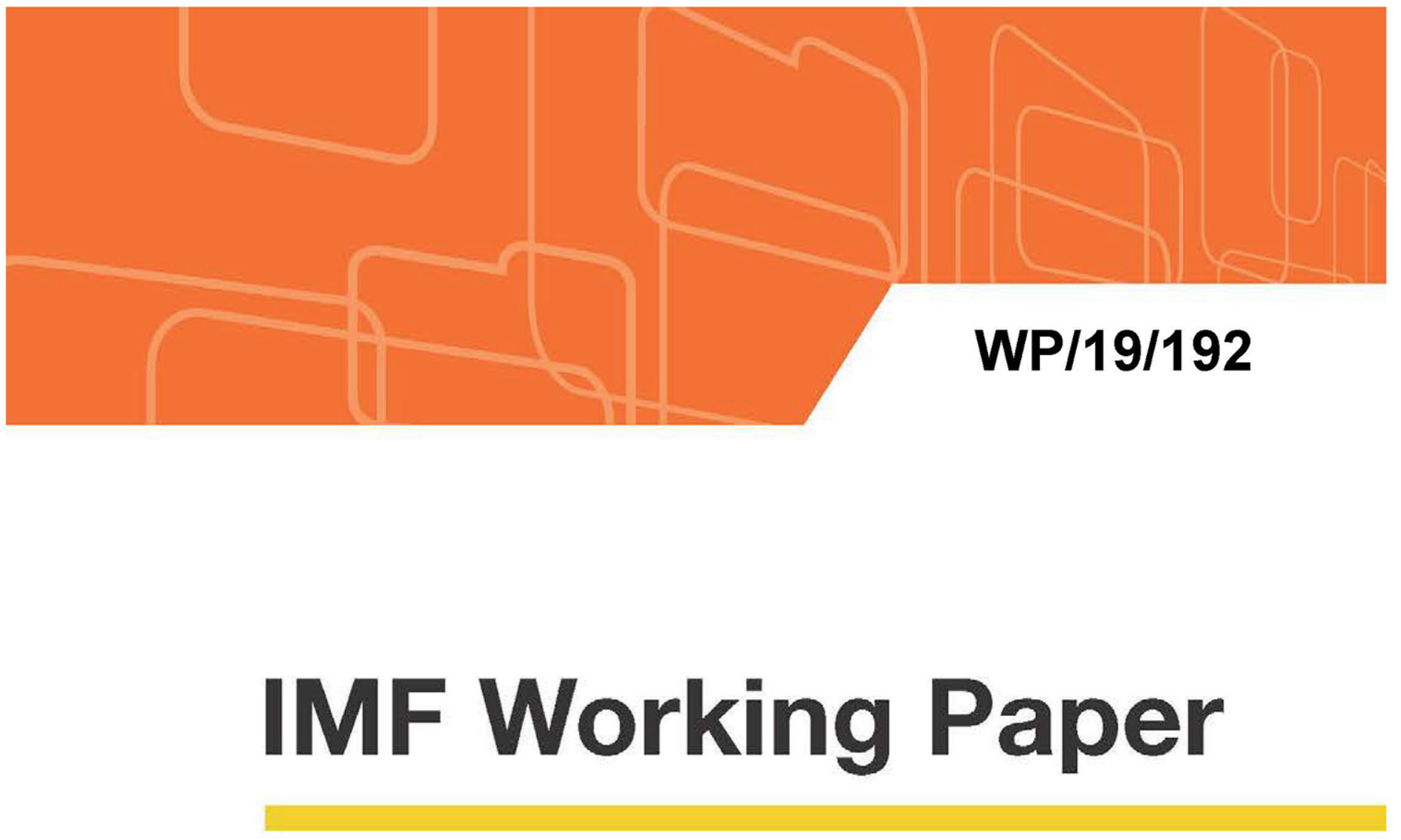

\title{
The Level REER model in the External Balance Assessment (EBA) Methodology
}

by Rui C. Mano, Carolina Osorio-Buitron, Luca Antonio Ricci, and Mauricio Vargas

IMF Working Papers describe research in progress by the author(s) and are published to elicit comments and to encourage debate. The views expressed in IMF Working Papers are those of the author(s) and do not necessarily represent the views of the IMF, its Executive Board, or IMF management. 


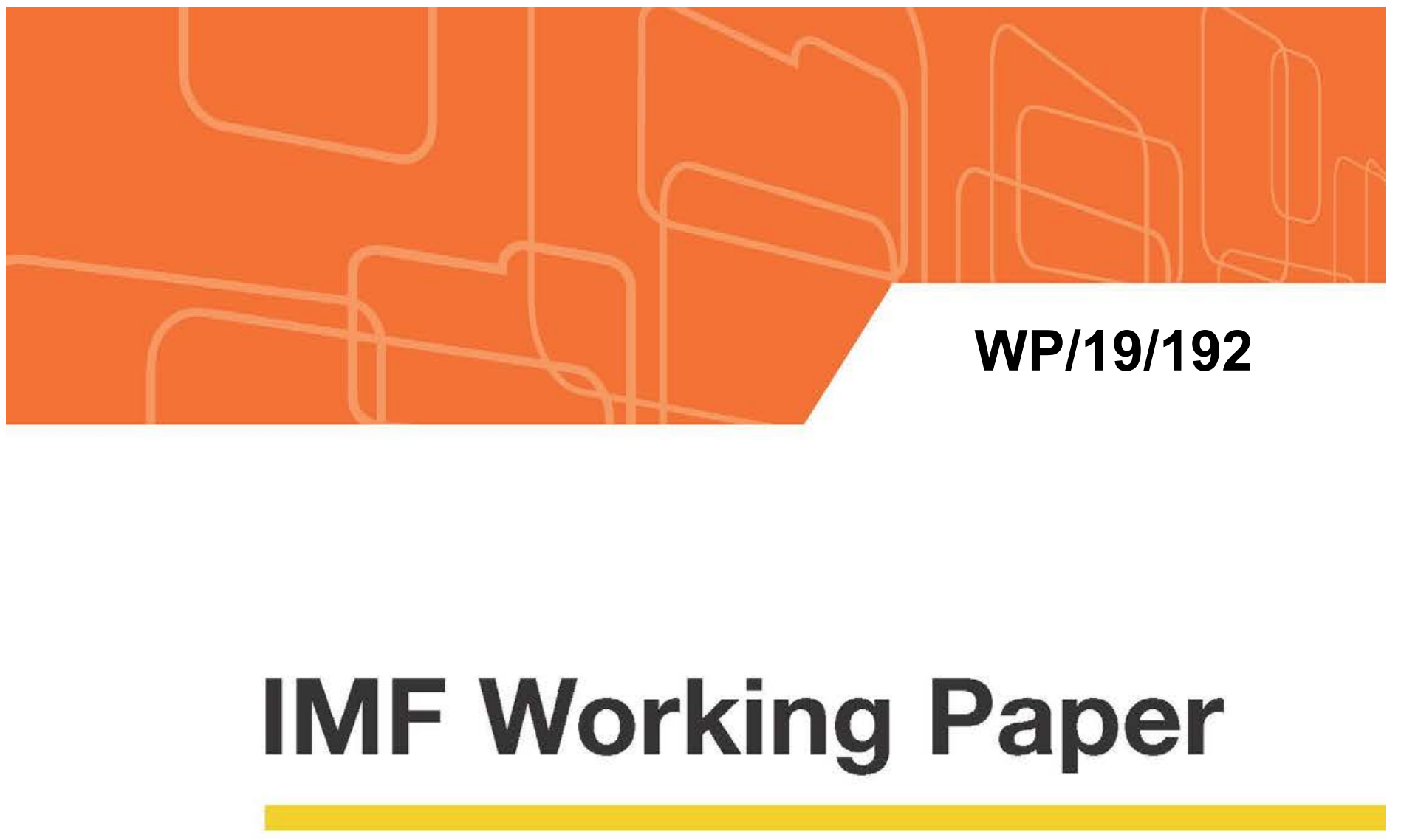

\section{The Level REER model in the External Balance Assessment (EBA) Methodology}

by Rui C. Mano, Carolina Osorio-Buitron, Luca Antonio Ricci, and Mauricio Vargas

IMF Working Papers describe research in progress by the author(s) and are published to elicit comments and to encourage debate. The views expressed in IMF Working Papers are those of the author(s) and do not necessarily represent the views of the IMF, its Executive Board, or IMF management.

I N T ER N A T I O N A L M O NETAR Y FUN D 


\title{
IMF Working Paper
}

Research, Strategy Policy and Review, and Western Hemisphere Departments

The Level REER model in the External Balance Assessment (EBA) Methodology
Prepared by Rui C. Mano, Carolina Osorio-Buitron, Luca Antonio Ricci and Mauricio $\operatorname{Vargas}^{1}$

Authorized for distribution by Luis Cubeddu, Rupa Duttagupta, and Luca Antonio Ricci

September 2019

IMF Working Papers describe research in progress by the author(s) and are published to elicit comments and to encourage debate. The views expressed in IMF Working Papers are those of the author(s) and do not necessarily represent the views of the IMF, its Executive Board, or IMF management.

\begin{abstract}
This paper offers an empirical model of the drivers of the level of the Real Effective Exchange Rate (REER) that is now part of the IMF's methodology for the assessment of external positions, including exchange rates. It constructs a measure of the level of the REER and it offers a panel regression that considers a large number of cross-sectional and time varying factors, guided by the extensive literature. Its main contribution is to enhance our understanding of the cross-sectional determinants of the level of the REER, while taking into account the time-series drivers. The framework accounts for the much larger cross-sectional variation of the level REER, and can better explain the time series variation of level REER when these are based on GDP-deflators rather than on consumer price indices. The latter suggest there may be merits to broadening the assessments to include such measures, although further analysis is required.
\end{abstract}

JEL Classification Numbers: F31, F32, O24

Keywords: Real exchange rate assessments; external imbalances; Author's E-Mail Address: rmano@,imf.org; COsorioBuitron@,imf.org; LRicci@imf.org; MVargas@,imf.org;

\footnotetext{
${ }^{1}$ We thank Luis Cubeddu, Mitali Das, Gian Maria Milesi-Ferretti, Steve Phillips and Pau Rabanal for helpful discussions. We also thank Alfredo Cuevas, Charles Kramer, Nicolas Magud, Cyril Rebillard, and Jasmin Sin for comments. Marola Castillo and Jair Rodriguez provided valuable research assistance. All errors are ours.
} 


\section{INTRODUCTION}

Assessing whether the overall external position, including exchange rates, are in line with fundamentals is a key mandate of the IMF, informing country-specific analysis of Article IV Staff Reports and supporting multilateral surveillance (IMF, 2007). In this context, assessing the degree of misalignment in real effective exchange rates (REERs)—or the extent to which REERs deviate from some notion of their equilibrium level - can provide information on the currency/price movements necessary to correct (excessive) external imbalances.

Furthermore, it is important to understand how cross-country differences, including the degree of trade and financial integration, affect the assessment of exchange rate and the role they play in a country's external adjustment process.

Traditional exchange rate assessments have been based on price-index measures that entail re-scaling RERs to a given value in the base year. As such, the empirical literature on the determinants of REER-indices has tended to focus either on time-series analyses of individual countries or panel fixed effects (FE) estimates. However, the FE estimation imposes the condition that the REER of each country is in equilibrium over the sample period and has the drawback of (i) making estimates less reliable for countries with short time data spans; and (ii) not permitting the exploration of how persistent policy distortions or slow-moving country features - including structural characteristics — may affect equilibrium exchange rate levels. ${ }^{2}$

By contrast, an empirical framework for price-level based REERs can exploit variation across countries as well as over time. The price-level REER model does not require the use of country FE, thus allowing for the possibility of persistent deviations of the exchange rate from its equilibrium, potentially reflecting unidentified structural distortions. Being able to explore the cross-country variation is essential to test for example the importance of the socalled Penn effect: the positive cross-country correlation between REER levels and GDP per capita, reflecting two supply side forces - productivity differentials (Balassa-Samuelson effect) and relative factor endowments (Kravis-Lipsey-Bhagwati effect) — as well as demand side factors, like the existence of non-homothetic preferences that reflect differences in consumption smoothing patterns across countries (Bergstrand, 1991).

This paper details the REER-level model, which forms part of the latest vintage of the IMF's external balance assessment (EBA) framework and complements the model based on REERindices. Among its contributions, the paper constructs price-level based REER measures and illustrates how model estimates are useful in the assessment of exchange rates, by enhancing our understanding of the cross-sectional determinants of the level of the REER. The REER level variable is constructed in two steps, combining cross-sectional information from PPP exchange rates and the time-series information contained in REER indices. Associated equilibrium exchange rate estimates suggest that proxies for the Balassa-Samuelson effect are key drivers of the relative price level of nontradable-to-tradable goods (see also Mano, 2017).

\footnotetext{
${ }^{2}$ Please see Cubeddu et al, 2019, for a detailed comparison of between the index- REER model and the levelREER model.
} 
This paper is organized as follows. Section II discusses the literature on exchange rate determination of price-index and price-level based RER measures. Section III describes the data, including the construction of the price-level RER measure, and empirical methodology. Section IV expands on the explanatory power of the benchmark regression. Section V presents the empirical results. And section VI concludes.

\section{REVIEW OF THE LITERATURE}

\section{A. Using macro-level Index RERs}

The literature on exchange rate determination using index measures of the real exchange rate is vast. Thus, here we lay out the main streams in broad terms and refer the reader to other papers with extensive references.

One strand of the literature has focused on statistical properties of prices and exchange rates. It reviews whether the law of one price or Purchasing Power Parity (PPP) holds. Burstein and Gopinath (2014) offer an extensive literature review of this strand, as does Rogoff (1996) for an earlier reference. The conclusion is generally that departures from the law of one price are persistent, common to many types of goods, and the adjustment is likely non-linear. Thus, short- to medium-term volatility of prices tends to be smaller than that of nominal exchange rates. A classical reference is Engel (1993) which itself cites earlier work. Because persistence was one of the key concerns, the literature also constructed and used very long spans of data. In this context, Sarno and Taylor (2002) review a large body of literature. Issues surrounding aggregation were brought to the fore in Taylor (2001) and Imbs, Mumtaz, Ravn and Rey (2005), and the literature turned mostly to micro-data studies since. ${ }^{3}$

The literature on exchange rate determination and drivers of exchange rates is also extensive. Philipps and others (2013), which introduced the IMF's EBA framework, contains many relevant references, as does its predecessor, the Consultative Group on exchange Rates, CGER (see IMF 2006). Other key references include: Cashin, Céspedes, and Sahay (2004), Christiansen et al. (2009), Dornbusch (1976), Edwards (1989), Edwards, and Ostry (1992), Engel and West (2005), Engel, Mark, and West (2008), Froot and Rogoff (1995), Hinkle and Montiel (1999), Obstfeld and Rogoff (1996), Ricci, Milesi-Ferretti, and Lee (2013), Rogoff (1996). The literature confirms the role of traditional factors, like the Balassa-Samuelson effect, fiscal variables, commodity prices, trade openness. Engel and West (2005) discuss the difficulty in linking exchange rates to macro variables using standard asset pricing methods, and Sarno and Schmeling (2014) extend the approach to a large panel of currencies and time.

\section{B. Aggregate level RER}

Figure 1 illustrates the challenge of explaining level RERs. It plots level RERs across countries against relative output per worker. Each color represents a different country. The chart shows significant differences in the level REER across countries (observations are widely dispersed across the vertical axis), as well as the high and positive correlation

\footnotetext{
${ }^{3}$ An early reference is Engel and Rogers (1996).
} 
between this variable and a measure of relative output per worker, which suggests that supply-side determinants play an important role (Penn effect).

The Penn Effect - the strong link between (real) income per capita and price levels in the cross-section of countries - was noted not long after the first few International Comparison Program (ICP) vintages came out in the 1970s (see Kravis and Lipsey (1983) for the earliest comprehensive treatment). A string of papers by the same authors further explored the regularity until Samuelson (1994) labeled the effect. Papers over the years have updated the original regressions using more recent vintages of the ICP and found that the Penn Effect is alive and well (Rogoff 1996, Frankel 2005, Cheung and Fujii 2014, Hassan 2016).

Bergstrand (1991) made an early attempt to explain the cross-section of the level of REER beyond income levels, by exploring the two main supply-side theories of REER determination-Balassa-Samuelson Effect focusing on the relative productivity of traded and nontraded sectors and the Kravis-Lipsey-Bhagwati Effect focusing on the relative capital intensity of traded and nontraded sectors - and the role of a demand channel through nonhomothetic preferences. He found that both supply and demand factors contribute to the Penn Effect. Since that early study, remarkably few papers have studied empirically the determinants of relative price levels in either a cross-sectional or panel setting until recently, except Broda (2006) which finds that the exchange rate regime is an important determinant of relative price levels in the cross section, beyond the Penn effect, trade and capital openness, and a country's total GDP in U.S. dollars, which are also significant. ${ }^{4}$

However, the publication of the latest ICP vintage pertaining to 2011 and its incorporation in the Penn World Tables, starting with version 8.1, spurred a string of recent papers. Fischer and Hossfeld (2014) propose a consistent set of multilateral indicators of price competitiveness and productivity for a broad group of 57 industrialized and emerging economies. Their procedure consists of the estimation of a panel regression, computation of multilateral benchmarks and forecast of misalignments. Berka and others (2015) find that relative sectoral productivity differences and labor market shocks can explain variation in the level of RER both in the cross section and time series. Mano (2017) constructs relative price levels for the traded and non-traded sectors and shows that the Balassa-Samuelson effect is key to explain cross-sectional variation of non-traded to traded prices as the theory would suggest, while the variance in traded prices alone can be accounted by other supply-side and demand-side factors. Also exploring cross-sectional variation, Cheung and others (2017) explore other determinants like capital openness, institutional quality, geography and the fact that a country is an oil exporter.

Closest to this paper, Fujii (2015) explores in a panel setting a large set of determinants, including sectoral productivity differentials, services share in GDP, trade and capital openness, government spending, exchange rate regime and natural resource endowment for advanced and developing countries separately. These determinants are largely found to be significant and with the expected sign, except: trade and capital openness, which are only significant for advanced countries; government spending, which is only significant in the

\footnotetext{
${ }^{4}$ Land size and current account to GDP were also included in Broda's benchmark specification but were not significant.
} 
case of developing countries; and crucially sectoral productivity differentials, which is positively related with relative price levels for developed countries but negatively for developing countries. More recently, Fischer (2019) emphasizes the importance of real exchange rate panel estimation methods and derives the distortion in the misalignment estimate for each of the conventional panel estimation methods.

\section{Other Price levels}

There are other studies of level RER that rely on micro-data. These include Gopinath, et. al. (2011) and Burstein and Jaimovich (2012), which use price data of a particular chain of supermarkets, Haskel and Wolf (2002) and Baxter and Landry (2017) using prices of final consumption goods of a particular retailer, and Cavallo, et. al. (2015) using data from online retailers.

\section{DAta ANd Methodology}

\section{A. The price-level based REER measure}

The REER level variable is constructed in a two-step process combining the cross-sectional dimension of PPP exchange rates with the time series dimension of the REER indices. First, REER level cross-country data for a benchmark year (2011) are obtained from the World Bank's International Comparison Program (ICP) — which computes (among other indicators) a GDP-based price level index relative to that of the United States. Subsequently, the REER level data is extended for the sample period (1990-2016), using IMF-INS REER indices rescaled to their 2011 value. The latter step ensures that the basket of goods used to compute the REER level is comparable over time. ${ }^{5}$ It also ensures the comparability of the analysis for exchange rate assessment with the one based on standard CPI-based REER indices, as both the level and index REER would use the same time series variation (which is all that matter with the fixed effect methodology employed when using index REER measures). An increase in the REER level measure indicates a real appreciation.

To sum up, the construction of the REER-level variable follows equation (1) below:

$$
\ln \left(R E E R_{\text {level }, t}\right)=\ln \left(P P P_{d i}^{b a s e=2011}\right)+\ln \left(R E E R_{\text {index }, t}^{\text {base }}=2011\right)-\ln (100)
$$

Where $P P P_{d i}^{b a s e=2011}$ is the ICP GDP-based price level relative to trading partners in the benchmark year of 2011, and $R E E R_{\text {index, }}^{\text {base }}=2011$ is the Fund's INS REER index (CPI-based) for year $t$ using 2011 as the base year.

Alternative level REER measures are constructed for the analysis in Section V.B., entailing the combination of other cross-sectional or time-series price levels or series, still combined via the above formula. The most notable is the one using the time series variation based on GDP deflators.

\footnotetext{
${ }^{5}$ PPP exchange rates from ICP use a different basket of goods in each benchmark year, making it difficult to interpret changes over time. By splicing PPP exchange rates with country-specific REER indices, time-series comparability of the consumption basket is ensured.
} 


\section{B. REER determinants: benchmark specification}

The REER determinants used in the analysis are grouped into fundamentalsmacroeconomic, cyclical, financial, and structural — and policy variables. A conceptual framework, explaining the channels through which each regressor affects the REER, is presented below, often indicating the consistency with the results of the same variables in the current account regressions. Indeed, the choice of the determinants is based on the key variables that have been essential in explaining the index-REER in the EBA methodology (see Phillips et al, 2013, and Cubeddu et al, 2019) coupled with the variables that others (see Mano, 2017) find important understanding the cross-sectional variation of price levels (e.g. proxies for the Balassa-Samuelson effect and the Bhagwati-Kravis-Lipsey effect, and the level of VAT). The sources of the variables are listed in Annex II, while an extensive description of all the variables is provided in Annex III.

\section{Macroeconomic Fundamentals}

Net Foreign Asset position (lagged). Countries with negative NFA positions should be expected to run trade surpluses and would need a more depreciated exchange rate to achieve this goal. This hypothesis implies that the coefficient on this variable should be positive, which is consistent with the empirical results.

Expected Real GDP growth 5 years ahead. The coefficient on this variable is expected to be positive, consistent with a negative sign in the current account regression: better growth prospects are associated with higher domestic demand, a lower current account, and a real exchange rate appreciation.

\section{Supply-side Fundamentals}

Output per worker (productivity) relative to top 3 economies (lagged). The sign of this variable is consistent with the classic argument that richer countries can be expected to have higher non-tradable prices and more appreciated exchange rates through the BalassaSamuelson effect.

Capital-labor ratio (lagged). This captures the Bhagwati-Kravis-Lipsey effect, whereby countries with higher capital-to-labor ratios have higher non-tradable prices and a more appreciated REER, since the non-tradable sector is typically more labor-intensive. The coefficient is found to be positive, as expected.

Ratio of traded/non-traded sector productivity (lagged). As another supply-side driver of REER levels, this variable captures the traditional Balassa-Samuelson effect, whereby countries with higher labor productivity in the tradable goods sector have higher domestic wages and non-tradable goods prices, implying a more appreciated exchange rate. The estimated coefficient is found to be positive, as expected. We therefore have two measures which are empirically successful in capturing the Balassa-Samuelson effect, as each measure is likely to be an imperfect proxy for the effect. 


\section{Cyclical Fundamentals ${ }^{6}$}

Commodity Terms of Trade. Commodity terms of trade are measured as the ratio of commodity export prices to commodity import prices. The coefficient has a positive sign, indicating that favorable commodity terms of trade are associated with a more appreciated exchange rate, consistent with theory. The choice of using commodity terms-of-trade instead of overall terms-of-trade lies in their exogeneity from the perspective of small-open economies.

\section{Financial Fundamentals}

Global Financial Conditions or Risk Aversion (interacted with capital account openness and reserve currency status, lagged). Increased risk aversion affects countries differently, depending on their degree of capital account openness and safe haven status. Increased risk aversion tends to depreciate the exchange rate for most countries but to appreciate the exchange rate of reserve currencies. The extent of these effects depends on each country's degree of capital account openness. To properly measure periods of very low global risk aversion, the VIX is expressed in terms of deviations from its historical average. The share of countries' own currency in global reserve holdings captures a reserve currency status.

\section{Structural Fundamentals}

Demographics. The demographic variables included in the model are population growth and old-age dependency ratio (OADR). Based on an OLG framework, Aloy and Gente (2009) show that higher population growth is related to a more appreciated currency. The authors argue that population growth is a good proxy for the birth rate and that, with selfish agents, aggregate wealth depends on the proportion of newborn individuals in the total population. Because newborn individuals do not have financial wealth, a decline in the birth rate leads to an increase in wealth per capita as well as consumption, thus causing a real appreciation. Similarly, increases in OADR have been found to raise the demand for non-tradable old-age related services relative to tradable commodities, which increases the relative price of nontraded goods and causes the real exchange rate to appreciate (Groneck and Kaufman; 2017). The empirical results are consistent with these theories.

Risks associated with Institutional Quality. Greater country risk - or the perception of such risk - is likely to be a disincentive to investment spending, leading to an improvement in the CA balance and a more depreciated exchange rate. A higher value for this indicator represents lower institutional risk, so the coefficient is expected to be positive, and the results support this prior.

Trade Openness (lagged). This variable is measured by the ratio of exports and imports to GDP. Trade liberalization generally lowers the domestic price of tradable goods, thus depreciating the real exchange rate $(\mathrm{Li}, 2004)$. The variable is lagged, because exchange rate

\footnotetext{
${ }^{6}$ Other measures of cyclical conditions, like the output gap, were not significant in the baseline regression and were thus dropped.
} 
fluctuations impact the numerator and denominator of the trade openness indicator. As expected, the coefficient has a negative sign.

VAT revenue. This indicator, expressed as a share of GDP, is a proxy for the effective rate of indirect taxation. Indirect taxes create a wedge between domestic and foreign prices, increasing domestic consumer prices and thereby appreciating the REER. The estimated coefficient in the REER-level model is found to have a positive sign but is at times insignificant depending on the specification.

Share of administered prices in the CPI. This variable is available only for a few transition economies which experienced a significant reduction in the share of administered prices during their economic transition towards a market economy. For the remaining countries, the variable is assumed to be 0 . Administered prices aim at keeping consumer prices lower, often of basic nontraded services, which leads to a depreciated REER. Hence, the coefficient on this variable is expected to be negative, and the results corroborate this prior.

\section{Policy Variables}

Monetary policy (interacted with capital account openness). The regression uses real shortterm interest rate differentials (i.e. adjusted for inflation differentials) to proxy for the effect of monetary policy on the exchange rate. A higher real interest rate differential should be related to a REER appreciation, and this relationship is stronger in countries with open capital accounts. The empirical results support this hypothesis.

Health Spending (lagged). This variable aims at proxying for the level of social safety net provision. When the safety net is insufficient, households would need to increase their precautionary saving, reducing domestic demand and devaluing the currency in real terms. The estimated coefficient for this variable is positive, which is consistent with theory.

Foreign Exchange Intervention (interacted with capital controls). If capital is imperfectly mobile, foreign exchange interventions (FXI) should affect nominal and real exchange rates. Hence, FXI/GDP ratio is interacted with a measure of capital controls. FXI is measured as the change in the stock of reserves in U.S. dollars, or the net reserves flow from the balance of payments statistics, as well as comparable operations in derivative markets. ${ }^{7}$ This broad measure of FXI builds on the notion that on- and off-balance sheet interventions have similar effects on exchange rates. The degree of capital mobility is based on the Quinn's index of capital controls (ranging from full mobility at 0 , to no mobility at 1 ). Due to endogeneity concerns - a country is most likely to accumulate reserves at a time when its currency is already strong, and to draw down reserves to defend a weakening currency-FXI is instrumented. Instruments include: (a) a measure of global accumulation of reserves, capturing what is known in the reserve accumulation literature as the "keeping-up with-theJoneses" effect, or the desire of countries to maintain FX liquidity (for precautionary

\footnotetext{
${ }^{7}$ Derivatives include aggregate short and long positions in forwards and futures in foreign currencies vis-à-vis the domestic currency (including the forward leg of currency swaps), and financial instruments denominated in foreign currency but settled by other means (for example, in domestic currency), as reported in the International Reserves and Foreign Currency Liquidity Template.
} 
motives) at par with peer emerging market countries (excluding own reserve accumulation for each country); (b) a measure of reserve adequacy linked to M2, which is defined as (M2-reserves)/GDP relative to the average emerging market group; and (c) an emerging market and developing economy dummy, in line with Bayoumi and others (2014), to capture the tendency of emerging markets and developing economies to accumulate reserves as part of their export-led growth strategies. The results indicate that FX purchases of foreign currency lead to a real depreciation, with smaller effects for countries where capital is more mobile.

Financial Excesses. Consistent with the current account estimates and the economic literature, the results indicate that credit booms - captured by private credit-to-GDP ratios above those implied by long-term trends computed with filtering techniques - increase domestic demand, leading to a lower current account and a more appreciated REER. ${ }^{8}$ However, the effect is not statistically significant.

Capital Controls. The effect of capital controls is included indirectly through its interactions with fundamental variables (global risk aversion) and policy variables (FXI and monetary policy).

The descriptive statistics and correlation among variables are presented in Table 1.

\section{Estimation method and sample}

The regression has a linear specification. The dependent variable is the (log) REER level of country $i$ at time $t$ as a linear function of a constant $\alpha$, macroeconomic fundamentals $X_{i t}$, and policies $P_{i t}$ - discussed in detail in the previous section-as well as an error term, $\varepsilon_{i t}$, which is assumed to be independently distributed with mean zero.

$$
R E E R_{i t}=\alpha+\beta X_{i t}+\gamma P_{i t}+\varepsilon_{i t}
$$

Most of the REER determinants are expressed as deviations from each country's trading partners weighted average, because these relative positions are what influence exchange rate movements. To mitigate endogeneity concerns, some variables are lagged, and a two-stage least squares instrumental variable (IV) approach is used to address the reverse causality between foreign exchange intervention (FXI) and the REER. This approach ensures that the estimation only captures movements in FXI that are not influenced by REER movements, thus establishing a causal relationship. The regression does not include fixed-effects (which is made possible by the presence of a cross-sectional dimension of the price-level REER, unlike the case of index-based REER), thus allowing for the ability to potentially capture misalignments related to unidentified (structural) distortions.

Finally, as in Phillips et al. (2013), the model is estimated with panel data methods that are compatible with a REER that is either stationary, or nonstationary but cointegrated with the regressors. Indeed, standard stationarity tests for the REER are inconclusive (see Appendix Table 1), while tests for regressors indicate the presence of unit roots for some of them. Overall, stationarity is hard to assess. Hence, we would like a methodology that is robust to

\footnotetext{
${ }^{8}$ See Dell'Ariccia and others (2012); Mendoza and Terrones (2012); and Landerretche, Gourinchas, and Valdés (2001).
} 
both, and so the choice is to estimate coefficients via OLS which are compatible with the data being either stationary, or nonstationary but cointegrated. When it comes to inference, in the case of stationarity, standard errors are corrected via the Newey-West HAC method, which accounts for heteroskedasticity both within countries and across countries, as well as serial correlation within countries; while in the case of nonstationarity, the relevance of variables is confirmed by the cointegration test, which is passed (see Appendix Table 2).

Finally, the sample covers 39 countries over the $1990-2016$ period $^{9}$, but the panel is unbalanced, reflecting data availability.

\section{Explanatory Power of THE BenChMark Regression}

\section{A. Benchmark regression}

Table 2 presents the estimates of the benchmark specification. As discussed earlier, most variables are statistically significant and have the expected signs. The R-squared of the model is very high (0.9), but the cointegration ensures the regression is not spurious in case we are in a non-stationary world. In other words, the results indicate that our regressions-which use levels of some variables that can be potentially non-stationary - capture a long-run equilibrating relationship, such that REER deviations from the values predicted by the independent variables can be persistent but are not permanent.

\section{B. Capturing the cross-sectional variation}

Figures 2-7 highlight the ability of the framework to capture the cross-sectional variation, which is the novelty of this exercise. They show the level REER, the fitted values, and the residuals, all in the same vertical scale for the range of the level REER. The purpose of the same scale is to allow comparability across charts of how much variation is in the original data and in the fitted values as opposed to the variation of residuals. Hence, employing the same scale across charts (and identifying substantial empty areas in some charts) offers a visual impression of the ability of the framework to capture the cross-sectional variation.

First, Figures 2-3 highlight the large variance of the level REER to be explained and show that about 90 percent of variance is coming from the cross-sectional dimension. These Figures report the log of level REER by country either in columns (Figure 2, sorted by the simple average of the REER level for each country) or over time (Figure 3). Figure 2 shows that the average range of the log level REER for each country (hence of the time series dimension) is about 0.5 , while the range of the cross-sectional mean across countries is almost 2. Figure 3 offers a similar picture on how much larger the cross-country variation is compared to the time series variation: the range of variation across lines (countries) is much larger than the range of variation within lines.

\footnotetext{
${ }^{9}$ The countries included are: Australia, Austria, Belgium, Brazil, Canada, Chile, China, Colombia, Czech Republic, Denmark, Finland, France, Germany, Greece, Hungary, India, Indonesia, Ireland, Italy, Japan, Republic of Korea, Malaysia, Mexico, Netherlands, New Zealand, Norway, Peru, Philippines, Poland, Portugal, Russian Federation, South Africa, Spain, Sweden, Switzerland, Thailand, Turkey, United Kingdom and United States.
} 
Figures 4-5 show that the benchmark regression fitted values exhibit virtually the same pattern as the original level-REER (shown instead in Figure 2-3). This implies that the benchmark regression is able to explain most of the variation of the level-REER. It is then not surprising that in Figure 6 residuals no longer present a declining pattern as in Figure 2 (recall that fixed effects are not included, which would otherwise ensure there would be no cross-country level difference in the residuals). At the same time Figure 7 shows a much more compressed range for the residual of the log level REER, of the order of 1 as opposed to about 2 in both figures 3 and 5 (this is made evident by the adoption of the same scale across charts). Figure 8 offers an equivalent perspective showing the significant overlap between actual and fitted. Despite the large and rich set of explanatory variables, some other important factors may still not be accounted for, especially those idyosincratic to particular economies.

\section{Which RHS matters more?}

The role played by each level REER determinant is examined by including one regressor at a time, the sequence of which is determined by the magnitude of the t-stats. The benchmark results indicate that the most important variable is output per-worker relative to the top 3 economies, providing strong empirical support to the Balassa-Samuelson effect. Indeed, the correlation between these two variables is very large in the cross-section and time series dimension (as had been shown in Figure 1). Moreover, relative output-per-worker alone explains almost 80 percent of the overall level REER variation (Table 3 ) as well as of the between country variation (Appendix Table 3).

\section{Robustness to Alternative Methodologies And Different Measures of the LEVEL-REER}

\section{A. Alternative estimation methods}

In Table 4, we explore the robustness of the regression to alternative estimation methods, i.e. OLS (column 1), fixed effects (col. 2), random effects (col. 3), and instrumental variables with fixed effects (col. 5), while our benchmark regression is reported in column 4. All estimates report robust $\mathrm{p}$-values to account for heteroskedasticity and/or serial correlation.

Of course, the main comparator that does not purge the cross-sectional variation is the OLS in column 1, which is impressively close to our benchmark both in terms of coefficients and significance. Methodologies in columns 2 and 3 absorb cross-sectional variation so they tend to downplay the role of variables whose main contribution is to explain the cross-sectional dimension, like capital stock and dependency ratio, while they alter the coefficient of NFA. It is interesting that when adding fixed effect (in column 5) to our preferred methodology (column 4), some of these variables that were substantially altered in columns 2 and 3, return close to our benchmark in terms of coefficient and significance (like reserves and real interest rates). At the same time, some of the variables that are not significant in the level REER benchmark (column 4) are significant in column 5, like VIX and private credit, suggesting they mainly contribute to explaining the time-series variation. When looking across all 
columns, despite the dramatically different methodologies, coefficient for variables that are expected to capture both the time series and the cross-sectional variation are quite stable.

\section{B. Alternative Measures of REER}

In this section, we show how baseline results change when using alternative measures of REERs. We find that the baseline results are overall very robust to using different REER concepts in the cross-sectional and time-series dimensions. A few variables appear sensitive to the choice of dependent variable, namely the dependency ratio, VAT revenue, expected GDP growth in the medium-term and real interest rate differentials interacted with capital controls, which do not seem to play a crucial role in the benchmark specification (Table 3).

Table 5 presents the benchmark specification in the column on the left, while the additional columns report regression related to different measures of the level of REER, which are based on the same time-series components, but alternative cross-sectional components: the Penn-World Table's (PWT) GDP-based REER (col 1), the ICP's Consumption-based REER (col 2), the PWT's Consumption-based REER (col 3), and the PWT's Domestic Absorptionbased REER ( $\operatorname{col} 4)$.

The regression results in Table 5 are remarkably robust across alternative measures of the level of the REER. All coefficients have the same sign and are usually similar in magnitude and statistical significance. The measures of fit are also similar across specifications. In particular, variables in Table 2 found to be crucial in the baseline specification are also robust across Table 5, except NFA to GDP which is robust across all regressions except column 1, where it is insignificant. Beyond those, a few other variables experience a change in significance levels across the specifications, namely expected GDP growth in the mediumterm, VAT revenue, and the real interest rate differential interacted with capital controls.

Figure 9 shows the country rank according to our preferred measure of REER - ICP's GDPbased REER - and alternatives level REER measures constructed via different crosssectional dimensions, as done in Table 5. A remarkable consistency across measures emerges, particularly with the PWT's measure of domestic absorption, which is expected since the ICP's GDP-based measure used in our benchmark is known to be inadequate at capturing well the price level of net exports (see Feenstra and others, 2016) and thus can be thought as a better proxy for the price of domestic absorption.

The benchmark results are also remarkably consistent when considering an alternative measure of the REER in the time-series dimension. Table 6 shows a similar robustness exercise as in Table 5, now using the same level REER concepts, but complemented with the time series dimension from GDP deflator-based indices, in contrast to our baseline which uses a CPI index for the time series dimension. The construction of a GDP deflator based REER has been argued by Bems and Johnson (2012). Again, all coefficients retain their basic sign and significance, including all the key coefficients of Table 2 . The exceptions are the dependency ratio, VAT revenue and real interest rate differentials interacted with capital controls, all of which were also found not robust in Table 5. The ranks of countries in the cross section are also very much aligned across REER measures when considering a GDP deflator-based REER (see Appendix Figure 1), even though the changes in REER seem less aligned (Appendix Figure 2). 
One important aspect of Table 6 is that the within-R2 is much higher than in the previous tables. This implies that the framework explains better the time-series variation of a real effective exchange rate based on GDP-deflator than one based on CPI indices. Hence, this suggests that going forward it may be interesting to consider complementing the external assessment via CPI-based REER exercise with one relying on a GDP-deflator-based REER.

Finally, we show that results are robust to using REER measures that are different from our benchmark in both the cross-sectional and time-series dimensions. Table 7 shows 4 different regressions. The first is our now familiar benchmark regression. The following 3 columns show results using PWT's GDP-based REER, Consumption-based REER and Absorptionbased REER, respectively. As before, most coefficients retain their sign and significance, and only a few are found not fully robust, significantly overlapping with those that were not robust to different measures of the REER in either the cross-section or the times-series. Appendix Figures 3 and 4 show that even across these different measures of REER there is a high degree of commonality, delivering a similar pattern as in Appendix Figures 1-2.

\section{Conclusions}

This paper describes an empirical model of the drivers of the level of the REER, which is now part of the IMF's EBA methodology. The key contributions are the construction of a new measure of the level REER and developing an empirical framework-guided by theoretical or empirical studies - to gauge the role of its cross-sectional and time-series determinants, which enhances our understanding of the cross-sectional determinants of the level of the REER.

The proposed measure of the level REER combines cross-sectional and time-series components. The cross-sectional dimension is given by countries' price level relative to the U.S., in a given year, based on the World Bank's 2011 International Comparison Program. This "bilateral" relative price is converted into an effective measure vis-à-vis all trading partners, using the IMF multilateral weighing system. The time series dimension comes from the IMF CPI-based REER, which maintains comparability with most of the existing studies on REER. Alternative measures of the level REER are also developed and tested, based on various combinations of the price datasets available (PWT and ICP) as well as alternative price definitions (GDP deflators, CPI, or absorption).

Our approach combines insights from existing empirical work related to the time-series of REERs and to the cross-sectional variation of relative prices. The benchmark regression for the level REER is as close as possible to the one adopted for the earlier CPI index-based REER in the IMF EBA methodology (Phillips et al, 2013, and Cubeddu et al, 2019). In addition, the framework builds on the theories of the drivers of relative price-level differences across countries, such as those underlying the Penn effect (GDP per capita and capital labor ratios). In doing so, it borrows from recent work by Mano (2017) and Mano and Castillo (2015).

The results indicate that the proposed empirical framework can account for numerous variables with both cross-section and the time-series explanatory power. In particular, the 
large cross-sectional variation of the level REER is mostly accounted for by the methodology - a novel finding. The study also documents the robustness of the results to alternative econometric methodologies, or to alternative measures of level REERs. While these are important transformations to the baseline specification, the results are reasonably robust.

The empirical framework captures much of the cross-sectional variation of the different level REER measures employed. At the same time, the framework can explain the time-series variation of a real effective exchange rate, especially if it is based on GDP-deflator rather than one based on the CPI. These findings suggest that consideration could be given to complementing the external assessment with REER measures that are based on the GDPdeflator. More generally, further effort is necessary to better capture the structural policies responsible for the cross-country variation of REER, although progress will depend on overcoming data constraints. 


\section{REFERENCES}

Baxter, M. and A. Landry, 2017, "IKEA: Product, Pricing, and Pass-Through," Research in Economics, vol. 71(3), pp. 507-520.

Bayoumi, T., J. Gagnon and C. Saborowski, 2014, "Official Financial Flows, Capital Mobility, and Global Imbalances,” IMF Working Paper 14/199.

Bems, R., and R. C. Johnson, 2012, “Value-Added Exchange Rates,” NBER WP 18498.

Bergstrand, J. H., 1991, "Structural Determinants of Real Exchange Rates and National Price Levels: Some Empirical Evidence," American Economic Review, vol. 81 (1), 325-334.

Berka, M., M. Devereux, and C. Engel, 2015, "Real Exchange Rates and Sectoral Productivity in the Eurozone," Working Papers, Department of Economics, The University of Auckland.

Broda, C., 2006, "Exchange Rate Regimes and National Price Levels," Journal of International Economic, vol. 70, pp. 52-81.

Burstein, A. and G. Gopinath, 2014, "International Prices and Exchange Rates," Handbook of International Economics, 4th ed., pp. 391-451.

Burstein, A. and N. Jaimovich, 2012, "Understanding Movements in Aggregate and ProductLevel Real Exchange Rates," Mimeo.

Cashin, P., L. F. Céspedes, and R. Sahay, 2004, "Commodity Currencies and The Real Exchange Rate," Journal of Development Economics, Vol. 75, pp. 239-68.

Cavallo, A., B. Neiman, and R. Rigobon, 2015, "Currency Unions, Product Introductions, and The Real Exchange Rate," IMF Economic Review, vol. 63(2), pp. 281-297.

Cheung, Y.-W., M. Chinn, and X. Nong, 2017, "Estimating Currency Misalignment Using the Penn Effect: It's Not as Simple as It Looks," International Finance, vol. 20(3), pp. 222-242.

Cheung, Y.-W. and E. Fujii, 2013, "Exchange Rate Misalignment Estimates-Sources of Differences," International Journal of Finance and Economics, vol. 19(2), pp. 91-121.

Christiansen, L., A. Prati, L. A. Ricci, and T. Tressel, 2010, "External Balance in Low Income Countries," NBER Seminar on International Macroeconomics, Vol. 6, No. 1.

Cubeddu, L. M., S. Krogstrup, G. Adler, P. Rabanal, M. C. Dao, S. A. Hannan, L. Juvenal, C. Osorio-Buitron, C. Rebillard, D. Garcia-Macia, C. Jones, J. Rodriguez, K. S. Chang, D. Gautam, Z. Wang, N. Li, 2019, "The External Balance Assessment (EBA) Methodology,” IMF Working Paper 19/65. 
Dell'Ariccia, G., I. Deniz, L. Laeven, H. Tong, B. Bakker, and J. Vandenbussche. 2012. Policies for Macrofinancial Stability: How to Deal with Credit Booms. IMF Staff Discussion Note 12/06, International Monetary Fund, Washington, DC.

Dornbusch, R., 1976, "Expectations and Exchange Rate Dynamics," Journal of Political Economy, Vol. 84, pp. 1161-76.

Edwards, S., 1989, "Real Exchange Rates, Devaluation, and Adjustment, Exchange Rate Policy in Developing Countries," The MIT Press, Cambridge, Mass.

Edwards, S. and J. D. Ostry, 1992, "Terms of Trade Disturbances, Real Exchange Rates, and Welfare: The Role of Capital Controls and Labor Market Distortions," Oxford Economic Papers, Vol. 44, No.1, pp. 20-34.

Engel, C. and K. D. West, 2005, "Exchange Rate and Fundamentals," Journal of Political Economy, Vol. 113, No. 3.43.

Engel, C., N. C. Mark, and K. D. West, 2008, "Exchange Rate Models Are Not as Bad as You Think," NBER Macroeconomics Annual, pp. 381-441.

Engel, C., 1993, "Real Exchange Rates and Relative Prices." Journal of Monetary Economics, vol. 32(1), pp. 35-50.

Fischer, C., 2019, "Equilibrium Real Exchange Rate Estimates Across Time and Space." Deutsche Bundesbank Discussion Paper No. 14/2019.

Fischer, C. and O. Hossfeld, 2014, "A consistent set of multilateral productivity approachbased indicators of price competitiveness - Results for Pacific Rim economies," Journal of International Money and Finance, Elsevier, vol. 49(PA), pages 152-169.

Frankel, J., 2005, "On the Renminbi: The Choice Between Adjustment Under a Fixed Exchange Rate and Adjustment Under a Flexible Rate," National Bureau of Economic Research, NBER Working Paper 11274.

Froot, K. A. and K. Rogoff, 1995, "Perspectives on PPP and Long-Run Real Exchange Rates," in Handbook of International Economics, Vol. 3, edited by Gene M. Grossman and Kenneth Rogoff (Amsterdam: Elsevier Science Publishers), pp. $1647-88$.

Fujii, E., 2015, "Reconsidering the Price-Income Relationship Across Countries," Pacific Economic Review, vol. 20(5), pp. 733-760.

Gopinath, G., P.-O. Gourinchas, C.-T. Hsieh, and N. Li, 2011, "International Prices, Costs, and Markup Differences," American Economic Review, vol. 101(6), pp. 2450-2486. 
Haskel, J. and H. Wolf, 2001, “The Law of One Price-A Case Study,” Scandinavian Journal of Economics, 103 (4), 545-558.

Hassan, F., 2016, "The Price of Development: The Penn-Balassa-Samuelson Effect Revisited," Journal of International Economics, 102, 291-309.

Hinkle L. and P. Montiel (eds.), "Exchange Rate Misalignment: Concepts and Measurements for Developing Countries," World Bank, Washington D.C, 1999, pp. 264-290.

IMF, 2007, "Review of the 1997 Decision", June 21,

IMF, 2006, "Methodology for CGER Exchange Rate Assessments,” Policy Paper, Research Department.

Imbs, J., H. Mumtaz, M. Ravn, and H. Rey, 2005, "PPP Strikes Back: Aggregation and the Real Exchange Rate," The Quarterly Journal of Economics, Vol. 120, No. 1, pp. 1-43.

Kravis, I. and R. Lipsey, 1983, “Toward an Explanation of National Price Levels," Princeton Studies in International Finance, No. 52.

Krugman, P. R., M. Obstfeld, and M. Melitz, 2014, "International Economics: Theory and Policy," 10th Edition, Pearson.

Landerretche, O., P.-O. Gourinchas, and R. Valdés. 2001. "Lending Booms: Latin American and the World." NBER Working Paper 8249, National Bureau of Economic Research, Cambridge, MA.

Li, X., "Trade Liberalization and Real Exchange Rate Movement," IMF Staff Papers, Vol. 51, No. 3, pp. 553-584.

Mano, R. C., 2017, "Beyond the Penn Effect: Supply Side Determinants of the Level of RER," Mimeo.

Mano, R. C. and M. Castillo, 2015, "The Level of Productivity in Traded and Non-Traded Sectors for a Large Panel of Countries," IMF Working Paper 15/48.

Mendoza, E., and M. E. Terrones. 2012. "An Anatomy of Credit Booms and their Demise." Journal Economía Chilena (The Chilean Economy) 15 (2): 4-32.

Obstfeld, M. and K. Rogoff, 1996, "Foundations of International Macroeconomics," (Cambridge, Massachusetts: MIT Press).

Phillips, S., L. Catao, L. Ricci, R. Bems, M. Das, J. D. Giovanni, F. Unsal, M. Castillo, J. Lee, J. Rodriguez, and M. Vargas, 2013, "The External Balance Assessment (EBA) Methodology," IMF Working Paper 13/272. 
Ricci, L. A., G. M. Milesi-Ferretti, and J. Lee, 2013, "Real Exchange Rates and Fundamentals: A Cross-Country Perspective," Journal of Money Credit and Banking, Vol. 45, Issue 5, pp. 845-865.

Rogoff, K., 1996, “The Purchasing Power Parity Puzzle,” Journal of Economic Literature, 1996, Vol. 34 (June), pp. 647-68.

Samuelson, P. A., 1994, "Facets of Balassa-Samuelson Thirty Years Later," Review of International Economics 2, 201-26.

Sarno, L. and M. Taylor, 2002, "Purchasing Power Parity and the Real Exchange Rate," IMF Staff Papers, Vol. 49, No. 1.

Sarno, L. and M. Schmeling, 2014, "Which Fundamentals Drive Exchange Rates? A CrossSectional Perspective," Journal of Money, Credit and Banking, Vol. 46, No. 2-3.

Taylor, A., 2001, "Potential Pitfalls for the Purchasing-Power-Parity Puzzle? Sampling and Specification Biases in Mean-Reversion Tests of the Law of One Price," Econometrica, Vol. 69, No. 2, pp. 473-498. 
Table 1: Descriptive Statistics and Correlations

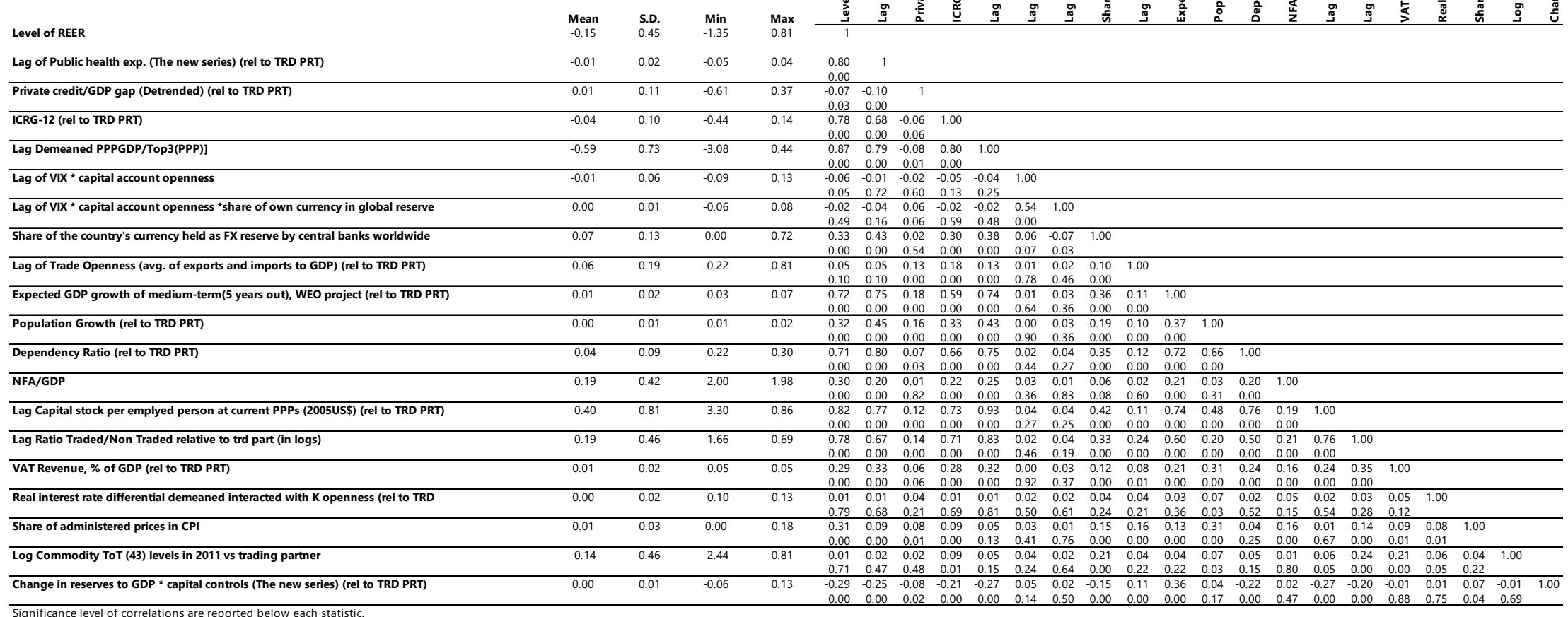


Table 2. Benchmark Specification

\begin{tabular}{|c|c|}
\hline VARIABLES & $\begin{array}{c}\text { Benchmark } \\
\text { ICP GDP } \\
\text { Based }\end{array}$ \\
\hline \multicolumn{2}{|l|}{ Cyclical Factors } \\
\hline Log Commodity ToT (43) levels in 2011 vs trading partner & $\begin{array}{c}0.06 * * * \\
(0.00)\end{array}$ \\
\hline \multicolumn{2}{|l|}{ Macroeconomic Fundamentals } \\
\hline NFA/GDP & $\begin{array}{c}0.06 * * * \\
(0.00)\end{array}$ \\
\hline Lag Demeaned PPPGDP/Top3(PPP)] & $\begin{array}{c}0.17 * * * \\
(0.00)\end{array}$ \\
\hline Expected GDP growth of medium-term( 5 years out), WEO project (rel to TRD PRT) & $\begin{array}{l}1.96 * * \\
(0.05)\end{array}$ \\
\hline Share of the country's currency held as FX reserve by central banks worldwide & $\begin{array}{c}-0.36 * * * \\
(0.00)\end{array}$ \\
\hline Lag Capital stock per emplyed person at current PPPs (2005US\$) (rel to TRD PRT) & $\begin{array}{c}0.11^{* * *} \\
(0.00)\end{array}$ \\
\hline Lag Ratio Traded/Non Traded relative to trd part (in logs) & $\begin{array}{c}0.18^{* * *} \\
(0.00)\end{array}$ \\
\hline \multicolumn{2}{|l|}{ Structural Fundamentals } \\
\hline Dependency Ratio (rel to TRD PRT) & $\begin{array}{l}0.36 * \\
(0.09)\end{array}$ \\
\hline Population Growth (rel to TRD PRT) & $\begin{array}{c}2.57 \\
(0.25)\end{array}$ \\
\hline ICRG-12 (rel to TRD PRT) & $\begin{array}{c}0.65 * * * \\
(0.00)\end{array}$ \\
\hline Lag of Trade Openness (avg. of exports and imports to GDP) (rel to TRD PRT) & $\begin{array}{c}-0.34^{* * *} \\
(0.00)\end{array}$ \\
\hline VAT Revenue, $\%$ of GDP (rel to TRD PRT) & $\begin{array}{c}0.66 \\
(0.26)\end{array}$ \\
\hline Share of administered prices in CPI & $\begin{array}{c}-2.81^{* * *} \\
(0.00)\end{array}$ \\
\hline Policy Variables & \\
\hline Real interest rate differential demeaned interacted with K openness (rel to TRD & $\begin{array}{l}0.59 * \\
(0.08)\end{array}$ \\
\hline Lag of Public health exp. (The new series) (rel to TRD PRT) & $\begin{array}{c}4.20 * * * \\
(0.00)\end{array}$ \\
\hline Change in reserves to GDP * capital controls (The new series) (rel to TRD PRT) & $\begin{array}{l}-3.56 * \\
(0.06)\end{array}$ \\
\hline Private credit/GDP gap (Detrended) (rel to TRD PRT) & $\begin{array}{c}0.03 \\
(0.65)\end{array}$ \\
\hline Lag of VIX * capital account openness & $\begin{array}{l}-0.15 \\
(0.25)\end{array}$ \\
\hline Lag of VIX * capital account openness *share of own currency in global reserve & $\begin{array}{c}0.83 \\
(0.13)\end{array}$ \\
\hline Constant & $\begin{array}{c}0.19 * * * \\
(0.00)\end{array}$ \\
\hline Observations & 990 \\
\hline R-squared & 0.90 \\
\hline RMSE & 0.1456 \\
\hline Number of Countries & 39 \\
\hline Within R-sq & 0.11 \\
\hline Between R-sq & 0.96 \\
\hline Overall R-sq & 0.90 \\
\hline
\end{tabular}

Robust pval in parentheses

${ }^{* * *} p<0.01,{ }^{* *} p<0.05,{ }^{*} p<0.1$

\section{CInternational Monetary Fund. Not for Redistribution}


Table 3: Sequential variable introduction based on t-stat (OLS method estimation)

\begin{tabular}{|c|c|c|c|c|c|c|c|c|c|c|c|c|c|c|c|c|c|c|c|c|}
\hline VARIABLES & $\begin{array}{l}1) \\
\text { ols } \\
\end{array}$ & $\begin{array}{l}\text { (2) } \\
\text { ols } \\
\end{array}$ & $\begin{array}{l}\text { (3) } \\
\text { ols }\end{array}$ & $\begin{array}{l}4) \\
\text { oLs } \\
\end{array}$ & $\begin{array}{l}5) \\
\text { OLS } \\
\end{array}$ & $\begin{array}{l}6) \\
\text { oLs } \\
\end{array}$ & $\begin{array}{l}\text { (7) } \\
\text { OLS } \\
\end{array}$ & $\begin{array}{l}(8) \\
\text { OLS } \\
\end{array}$ & $\begin{array}{l}9) \\
\text { OLS } \\
\end{array}$ & $\begin{array}{l}\text { (10) } \\
\text { OLS } \\
\end{array}$ & $\begin{array}{l}\text { (11) } \\
\text { OLS } \\
\end{array}$ & $\begin{array}{l}\text { (12) } \\
\text { OLS }\end{array}$ & $\begin{array}{l}\text { (13) } \\
\text { OLS }\end{array}$ & $\begin{array}{l}\text { (14) } \\
\text { OLS }\end{array}$ & $\begin{array}{l}\text { (15) } \\
\text { OLS } \\
\end{array}$ & $\begin{array}{l}16) \\
\text { OLS } \\
\end{array}$ & $\begin{array}{l}\text { (17) } \\
\text { OLS }\end{array}$ & $\begin{array}{l}(18) \\
\text { OLs }\end{array}$ & $\begin{array}{l}\text { (19) } \\
\text { OLS }\end{array}$ & $\begin{array}{c}(20) \\
\text { IV-REG }\end{array}$ \\
\hline Lag Demeaned PPPGDP/Top3(PPP)] & $\begin{array}{c}0.53 * * * \\
(0.00)\end{array}$ & $\begin{array}{c}0.52^{* * *} \\
(0.00)\end{array}$ & $\begin{array}{c}0.40 * * * \\
(0.00)\end{array}$ & $\begin{array}{c}0.33^{* * *} \\
(0.00)\end{array}$ & $\begin{array}{c}0.34^{* * *} \\
(0.00)\end{array}$ & $\begin{array}{c}0.35 * * * \\
(0.00)\end{array}$ & $\begin{array}{c}0.31 * * * \\
(0.00)\end{array}$ & $\begin{array}{c}0.22 * * * \\
(0.00)\end{array}$ & $\begin{array}{c}0.21 * * * \\
(0.00)\end{array}$ & $\begin{array}{c}0.20^{* * *} \\
(0.00)\end{array}$ & $\begin{array}{c}0.19 * * * \\
(0.00)\end{array}$ & $\begin{array}{c}0.18 * * * \\
(0.00)\end{array}$ & $\begin{array}{c}0.18^{* * *} \\
(0.00)\end{array}$ & $\begin{array}{c}0.18 * * * \\
(0.00)\end{array}$ & $\begin{array}{c}0.18^{* * *} \\
(0.00)\end{array}$ & $\begin{array}{c}0.18^{* * *} \\
(0.00)\end{array}$ & $\begin{array}{c}0.18^{* * *} \\
(0.00)\end{array}$ & $\begin{array}{c}0.18^{* * *} \\
(0.00)\end{array}$ & $\begin{array}{c}0.17^{* * *} \\
(0.00)\end{array}$ & $\begin{array}{c}0.17 * * * \\
(0.00)\end{array}$ \\
\hline Share of administered prices in CPI & & $\begin{array}{c}-3.44 * * * \\
(0.00)\end{array}$ & $\begin{array}{c}-3.26 * * * \\
(0.00)\end{array}$ & $\begin{array}{c}-3.16^{* * * *} \\
(0.00)\end{array}$ & $\begin{array}{c}-2.92^{* * *} \\
(0.00)\end{array}$ & $\begin{array}{c}-3.04 * * * \\
(0.00)\end{array}$ & $\begin{array}{c}-2.87^{* * *} \\
(0.00)\end{array}$ & $\begin{array}{c}-2.95 * * \\
(0.00)\end{array}$ & $\begin{array}{c}-2.91^{* * *} \\
(0.00)\end{array}$ & $\begin{array}{c}-2.84^{* * *} \\
(0.00)\end{array}$ & $\begin{array}{c}-2.82 * * * \\
(0.00)\end{array}$ & $\begin{array}{c}-2.87 * * * \\
(0.00)\end{array}$ & $\begin{array}{c}-2.89 * * * * \\
(0.00)\end{array}$ & $\begin{array}{c}-2.90 * * * \\
(0.00)\end{array}$ & $\begin{array}{c}-2.94^{* * *} \\
(0.00)\end{array}$ & $\begin{array}{c}-2.84^{* * *} \\
(0.00)\end{array}$ & $\begin{array}{c}-2.84^{* * *} \\
(0.00)\end{array}$ & $\begin{array}{c}-2.83^{* * *} \\
(0.00)\end{array}$ & $\begin{array}{c}-2.81^{* * *} \\
(0.00)\end{array}$ & $\begin{array}{c}-2.81^{* * *} \\
(0.00)\end{array}$ \\
\hline Lag of Public health exp. (The new series) (rel to TRD PRT) & & & $\begin{array}{c}6.00 * * * \\
(0.00)\end{array}$ & $\begin{array}{c}5.50^{* * *} \\
(0.00)\end{array}$ & $\begin{array}{c}4.30^{* * *} \\
(0.00)\end{array}$ & $\begin{array}{c}4.98^{* * *} \\
(0.00)\end{array}$ & $\begin{array}{c}4.81^{* * *} \\
(0.00)\end{array}$ & $\begin{array}{c}4.46 * * * \\
(0.00)\end{array}$ & $\begin{array}{c}4.53 * * * \\
(0.00)\end{array}$ & $\begin{array}{c}4.46 * * * \\
(0.00)\end{array}$ & $\begin{array}{c}4.44 * * * \\
(0.00)\end{array}$ & $\begin{array}{c}4.56 * * * \\
(0.00)\end{array}$ & $\begin{array}{c}4.55 * * * \\
(0.00)\end{array}$ & $\begin{array}{c}4.78^{* * * *} \\
(0.00)\end{array}$ & $\begin{array}{c}4.45 * * * \\
(0.00)\end{array}$ & $\begin{array}{c}4.43 * * * \\
(0.00)\end{array}$ & $\begin{array}{c}4.43 * * * \\
(0.00)\end{array}$ & $\begin{array}{c}4.45^{* * *} \\
(0.00)\end{array}$ & $\begin{array}{c}4.25^{* * *} \\
(0.00)\end{array}$ & $\begin{array}{c}4.20 * * * \\
(0.00)\end{array}$ \\
\hline ICRG-12 (rel to TRD PRT) & & & & $\begin{array}{c}0.75^{* * *} \\
(0.00)\end{array}$ & $\begin{array}{c}0.90 * * * \\
(0.00)\end{array}$ & $\begin{array}{c}0.88^{* * *} \\
(0.00)\end{array}$ & $\begin{array}{c}0.84 * * * \\
(0.00)\end{array}$ & $\begin{array}{c}0.86 * * * \\
(0.00)\end{array}$ & $\begin{array}{c}0.76 * * * \\
(0.00)\end{array}$ & $\begin{array}{c}0.76^{* * *} \\
(0.00)\end{array}$ & $\begin{array}{c}0.76 * * * \\
(0.00)\end{array}$ & $\begin{array}{c}0.74 * * * \\
(0.00)\end{array}$ & $\begin{array}{c}0.74^{* * *} \\
(0.00)\end{array}$ & $\begin{array}{c}0.73^{* * *} \\
(0.00)\end{array}$ & $\begin{array}{c}0.69 * * * \\
(0.00)\end{array}$ & $\begin{array}{c}0.68 * * * \\
(0.00)\end{array}$ & $\begin{array}{c}0.68 * * * \\
(0.00)\end{array}$ & $\begin{array}{c}0.68^{* * *} \\
(0.00)\end{array}$ & $\begin{array}{c}0.67^{* * *} \\
(0.00)\end{array}$ & $\begin{array}{c}0.65 * * \\
(0.00)\end{array}$ \\
\hline Lag of Trade Openness (avg. of exports and imports to GDP) (rel to TRD PRT) & & & & & $\begin{array}{c}-0.28^{* * *} \\
(0.00)\end{array}$ & $\begin{array}{c}-0.30 * * * \\
(0.00)\end{array}$ & $\begin{array}{c}-0.34 * * * \\
(0.00)\end{array}$ & $\begin{array}{c}-0.35 * * * \\
(0.00)\end{array}$ & $\begin{array}{c}-0.36 * * * \\
(0.00)\end{array}$ & $\begin{array}{c}-0.36 * * * \\
(0.00)\end{array}$ & $\begin{array}{c}-0.35 * * * \\
(0.00)\end{array}$ & $\begin{array}{c}-0.34 * * * \\
(0.00)\end{array}$ & $\begin{array}{c}-0.34 * * * \\
(0.00)\end{array}$ & $\begin{array}{c}-0.35 * * * \\
(0.00)\end{array}$ & $\begin{array}{c}-0.34 * * * \\
(0.00)\end{array}$ & $\begin{array}{c}-0.35 * * * \\
(0.00)\end{array}$ & $\begin{array}{c}-0.35 * * * \\
(0.00)\end{array}$ & $\begin{array}{c}-0.35 * * * \\
(0.00)\end{array}$ & $\begin{array}{c}-0.35 * * * \\
(0.00)\end{array}$ & $\begin{array}{c}-0.34 * * 1 \\
(0.00)\end{array}$ \\
\hline Share of the country's currency held as FX reserve by central banks worldwide & & & & & & $\begin{array}{c}-0.31 * * * \\
(0.00)\end{array}$ & $\begin{array}{c}-0.32^{* * *} \\
(0.00)\end{array}$ & $\begin{array}{c}-0.36 * * * \\
(0.00)\end{array}$ & $\begin{array}{c}-0.41 * * * \\
(0.00)\end{array}$ & $\begin{array}{c}-0.39 * * * \\
(0.00)\end{array}$ & $\begin{array}{c}-0.39 * * * \\
(0.00)\end{array}$ & $\begin{array}{c}-0.40 * * * \\
(0.00)\end{array}$ & $\begin{array}{c}-0.41^{* * *} \\
(0.00)\end{array}$ & $\begin{array}{c}-0.41^{* * *} \\
(0.00)\end{array}$ & $\begin{array}{c}-0.41^{* * *} \\
(0.00)\end{array}$ & $\begin{array}{c}-0.41^{* * *} \\
(0.00)\end{array}$ & $\begin{array}{c}-0.40^{* * *} \\
(0.00)\end{array}$ & $\begin{array}{c}-0.39 * * * \\
(0.00)\end{array}$ & $\begin{array}{c}-0.37^{* * *} \\
(0.00)\end{array}$ & $\begin{array}{c}-0.36 * * * \\
(0.00)\end{array}$ \\
\hline Lag Ratio Traded/Non Traded relative to trd part (in logs) & & & & & & & $\begin{array}{c}0.11 * * * \\
(0.00)\end{array}$ & $\begin{array}{c}0.12 * * * \\
(0.00)\end{array}$ & $\begin{array}{c}0.16 * * \\
(0.00)\end{array}$ & $\begin{array}{c}0.16^{* * *} \\
(0.00)\end{array}$ & $\begin{array}{c}0.16 * * * \\
(0.00)\end{array}$ & $\begin{array}{c}0.17 * * * \\
(0.00)\end{array}$ & $\begin{array}{c}0.18 * * * \\
(0.00)\end{array}$ & $\begin{array}{c}0.18^{* * *} \\
(0.00)\end{array}$ & $\begin{array}{c}0.19 * * * \\
(0.00)\end{array}$ & $\begin{array}{c}0.19 * * * \\
(0.00)\end{array}$ & $\begin{array}{c}0.19 * * * \\
(0.00)\end{array}$ & $\begin{array}{c}0.19 * * * * \\
(0.00)\end{array}$ & $\begin{array}{c}0.18^{* * *} \\
(0.00)\end{array}$ & $\begin{array}{c}0.18^{* * *} \\
(0.00)\end{array}$ \\
\hline Lag Capital stock per emplyed person at current PPPs (2005US\$) (rel to TRD PRT) & & & & & & & & $\begin{array}{c}0.09 * * * \\
(0.00)\end{array}$ & $\begin{array}{c}0.10 * * * \\
(0.00)\end{array}$ & $\begin{array}{c}0.10^{* * * *} \\
(0.00)\end{array}$ & $\begin{array}{c}0.10^{* * * *} \\
(0.00)\end{array}$ & $\begin{array}{c}0.10^{* * * *} \\
(0.00)\end{array}$ & $\begin{array}{c}0.11 * * * \\
(0.00)\end{array}$ & $\begin{array}{c}0.11 * * * \\
(0.00)\end{array}$ & $\begin{array}{c}0.11 * * * \\
(0.00)\end{array}$ & $\begin{array}{c}0.11 * * * \\
(0.00)\end{array}$ & $\begin{array}{c}0.111^{* * *} \\
(0.00)\end{array}$ & $\begin{array}{c}0.11^{* * *} \\
(0.00)\end{array}$ & $\begin{array}{c}0.11^{* * *} \\
(0.00)\end{array}$ & $\begin{array}{c}0.11 * * \\
(0.00)\end{array}$ \\
\hline Log Commodity ToT (43) levels in 2011 vs trading partner & & & & & & & & & $\begin{array}{l}0.05 * * \\
(0.01)\end{array}$ & $\begin{array}{l}0.05 * * \\
(0.01)\end{array}$ & $\begin{array}{l}0.05 * * \\
(0.01)\end{array}$ & $\begin{array}{l}0.05 * * \\
(0.01)\end{array}$ & $\begin{array}{c}0.06^{* * *} \\
(0.01)\end{array}$ & $\begin{array}{c}0.06^{* * *} \\
(0.01)\end{array}$ & $\begin{array}{c}0.06 * * * \\
(0.01)\end{array}$ & $\begin{array}{c}0.06 * * * \\
(0.00)\end{array}$ & $\begin{array}{c}0.06 * * * \\
(0.00)\end{array}$ & $\begin{array}{c}0.06^{* * *} \\
(0.00)\end{array}$ & $\begin{array}{c}0.06^{* * *} \\
(0.00)\end{array}$ & $\begin{array}{c}0.06^{* * *} \\
(0.00)\end{array}$ \\
\hline NFA/GDP & & & & & & & & & & $\begin{array}{l}0.04 * * \\
(0.02)\end{array}$ & $\begin{array}{l}0.04 * * \\
(0.01)\end{array}$ & $\begin{array}{l}0.04^{* *} \\
(0.02)\end{array}$ & $\begin{array}{l}0.04 * * \\
(0.03)\end{array}$ & $\begin{array}{l}0.04^{* *} \\
(0.02)\end{array}$ & $\begin{array}{l}0.04 * * \\
(0.02)\end{array}$ & $\begin{array}{l}0.04 * * \\
(0.03)\end{array}$ & $\begin{array}{l}0.04 * * \\
(0.03)\end{array}$ & $\begin{array}{l}0.04^{* *} \\
(0.03)\end{array}$ & $\begin{array}{l}0.04^{* *} \\
(0.01)\end{array}$ & $\begin{array}{c}0.06 * * * \\
(0.00)\end{array}$ \\
\hline Change in reserves to GDP * capital controls (The new series) (rel to TRD PRT) & & & & & & & & & & & $\begin{array}{c}-1.04 * * \\
(0.03)\end{array}$ & $\begin{array}{l}-0.92^{*} \\
\left(0.055^{2}\right.\end{array}$ & $\begin{array}{l}-0.91^{*} \\
(0.05)\end{array}$ & $\begin{array}{c}-1.06 * * \\
(0.02)\end{array}$ & $\begin{array}{c}-1.12^{* *} \\
(0.02)\end{array}$ & $-1.06 * *$ & $-1.07^{* *}$ & $-1.05^{* *}$ & $-1.11^{* *}$ & $-3.56^{*}$ \\
\hline Private credit/GDP gap (Detrended) (rel to TRD PRT) & & & & & & & & & & & & $0.13^{*}$ & $0.13^{*}$ & 0.11 & 0.11 & $\begin{array}{l}0.027 \\
0.10\end{array}$ & 0.09 & 0.09 & $\begin{array}{l}0.07 \\
0.07\end{array}$ & 0.03 \\
\hline & & & & & & & & & & & & $(0.06)$ & $(0.06)$ & (0.11) & (0.10) & (0.18) & (0.19) & $(0.21)$ & (0.33) & $(0.65)$ \\
\hline Real interest rate differential demeaned interacted with $\mathrm{K}$ openness (rel to TRD & & & & & & & & & & & & & $0.56^{*}$ & $0.55^{*}$ & 0.54 & $0.57^{*}$ & $0.57^{*}$ & 0.55 & $0.59^{*}$ & $0.59^{*}$ \\
\hline Expected GDP growth of medium-term(5 years out), WEO project (rel to TRD PRT) & & & & & & & & & & & & & $(0.10)$ & $\begin{array}{c}(0.09) \\
0.82\end{array}$ & $\begin{array}{c}(0.11) \\
0.99\end{array}$ & $\begin{array}{l}(0.09) \\
1.13\end{array}$ & $\begin{array}{ll}(0.09) \\
1.15\end{array}$ & $\begin{array}{l}(0.10) \\
1.13\end{array}$ & $\begin{array}{l}(0.08) \\
1.19\end{array}$ & $\begin{array}{l}(0.08) \\
1.96 * *\end{array}$ \\
\hline & & & & & & & & & & & & & & $(0.32)$ & $(0.23)$ & $(0.16)$ & (0.16) & (0.17) & (0.14) & $(0.05)$ \\
\hline Dependency Ratio (rel to TRD PRT) & & & & & & & & & & & & & & & 0.18 & 0.28 & 0.28 & 0.28 & 0.32 & $0.36^{*}$ \\
\hline & & & & & & & & & & & & & & & $(0.32)$ & $(0.17)$ & $(0.17)$ & (0.17) & (0.14) & $(0.09)$ \\
\hline Population Growth (rel to TRD PRT) & & & & & & & & & & & & & & & & 2.16 & 2.1 & 2.1 & 2.83 & 2.57 \\
\hline & & & & & & & & & & & & & & & & $(0.26)$ & $(0.26)$ & (0.27) & $(0.21)$ & $(0.25)$ \\
\hline Lag of VIX * capital account openness * share of own currency in global reserve & & & & & & & & & & & & & & & & & 0.34 & 0.85 & 0.84 & 0.83 \\
\hline & & & & & & & & & & & & & & & & & $(0.35)$ & (0.11) & $(0.12)$ & $(0.13)$ \\
\hline Lag of VIX * capital account openness & & & & & & & & & & & & & & & & & & -0.17 & -0.17 & -0.15 \\
\hline & & & & & & & & & & & & & & & & & & (0.20) & $(0.20)$ & $(0.25)$ \\
\hline VAT Revenue, \% of GDP (rel to TRD PRT) & & & & & & & & & & & & & & & & & & & 0.47 & 0.66 \\
\hline Constant & $\begin{array}{c}0.11^{* * * *} \\
(0.00)\end{array}$ & $\begin{array}{c}0.19 * * * \\
(0.00)\end{array}$ & $\begin{array}{c}0.18^{* * *} \\
(0.00)\end{array}$ & $\begin{array}{c}0.16^{* * *} \\
(0.00)\end{array}$ & $\begin{array}{c}0.18 * * * \\
(0.00)\end{array}$ & $\begin{array}{c}0.21^{* * *} \\
(0.00)\end{array}$ & $\begin{array}{c}0.21^{* * *} \\
(0.00)\end{array}$ & $\begin{array}{c}0.19^{* * *} \\
(0.00)\end{array}$ & $\begin{array}{c}0.20 * * * \\
(0.00)\end{array}$ & $\begin{array}{c}0.20^{* * *} \\
(0.00)\end{array}$ & $\begin{array}{c}0.20^{* * *} \\
(0.00)\end{array}$ & $\begin{array}{c}0.20^{* * *} \\
(0.00)\end{array}$ & $\begin{array}{c}0.20 * * * \\
(0.00)\end{array}$ & $\begin{array}{c}0.22^{* * * *} \\
(0.00)\end{array}$ & $\begin{array}{c}0.20 * * * \\
(0.00)\end{array}$ & $\begin{array}{c}0.20 * * * \\
(0.00)\end{array}$ & $\begin{array}{c}0.20 * * * \\
(0.00)\end{array}$ & $\begin{array}{c}0.20^{* * *} \\
(0.00)\end{array}$ & $\begin{array}{c}(0.41) \\
0.19 * * * \\
(0.00)\end{array}$ & $\begin{array}{c}(0.26) \\
0.19^{* * *} \\
(0.00)\end{array}$ \\
\hline bserv & 990 & 990 & 990 & 990 & 99 & 990 & 990 & $9 \mathrm{~s}$ & $9 \mathrm{cs}$ & 99 & 990 & 99 & 99 & & 990 & 990 & 990 & 990 & 990 & 990 \\
\hline squared & 0.16 & 83 & 0.85 & 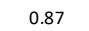 & 0.88 & 0. & 0. & 0.8 & 0. & 0. & 0. & 0 & 0. & 0. & & 0.90 & 0. & 0. & 0. & \\
\hline RMSE & 0.2186 & 0.1834 & 0.1698 & 0.1633 & 0.1558 & 0.1514 & 0.1490 & 0.1470 & 0.1457 & 0.1450 & 0.1445 & 0.1439 & 0.1436 & 0.1435 & 0.1434 & 0.1432 & 0.1433 & 0.1431 & 0.1430 & 0.1456 \\
\hline
\end{tabular}

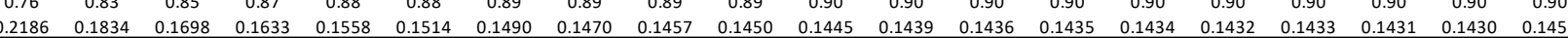

Robust pval in parentheses
$* * * p<0.01, * * p<0.05,{ }^{*} p<0.1$ 
Table 4. Comparison of Benchmark Specification to Alternative Estimation Methods

\begin{tabular}{|c|c|c|c|c|c|}
\hline & (1) & (2) & (3) & (4) & (5) \\
\hline VARIABLES & OLS & $\mathrm{FE}$ & RE & IV-Reg & IV-Reg, FE \\
\hline \multicolumn{6}{|l|}{ Cyclical Factors } \\
\hline Log Commodity ToT (43) levels in 2011 vs trading partner & $\begin{array}{c}0.06^{* * *} \\
(0.00)\end{array}$ & $\begin{array}{l}0.09 * * \\
(0.01)\end{array}$ & $\begin{array}{l}0.05^{*} \\
(0.07)\end{array}$ & $\begin{array}{c}0.06 * * * \\
(0.00)\end{array}$ & $\begin{array}{c}0.08^{* * *} \\
(0.00)\end{array}$ \\
\hline \multicolumn{6}{|l|}{ Macroeconomic Fundamentals } \\
\hline NFA/GDP & $\begin{array}{c}0.04^{* * *} \\
(0.00)\end{array}$ & $\begin{array}{c}-0.13^{* * *} \\
(0.00)\end{array}$ & $\begin{array}{c}-0.11 * * * \\
(0.00)\end{array}$ & $\begin{array}{c}0.06^{* * *} \\
(0.00)\end{array}$ & $\begin{array}{c}-0.12^{* * *} \\
(0.00)\end{array}$ \\
\hline Lag Demeaned PPPGDP/Top3(PPP)] & $\begin{array}{c}0.17^{* * *} \\
(0.00)\end{array}$ & $\begin{array}{l}0.21^{* *} \\
(0.02)\end{array}$ & $\begin{array}{c}0.35^{* * *} \\
(0.00)\end{array}$ & $\begin{array}{c}0.17^{* * *} \\
(0.00)\end{array}$ & $\begin{array}{c}0.20 * * * \\
(0.00)\end{array}$ \\
\hline Expected GDP growth of medium-term(5 years out), WEO project (rel to TRD PRT) & $\begin{array}{l}1.19 * * \\
(0.04)\end{array}$ & $\begin{array}{l}1.66^{*} \\
(0.08)\end{array}$ & $\begin{array}{c}1.36 \\
(0.19)\end{array}$ & $\begin{array}{l}1.96 * * \\
(0.05)\end{array}$ & $\begin{array}{c}1.93^{* * *} \\
(0.01)\end{array}$ \\
\hline Share of the country's currency held as FX reserve by central banks worldwide & $\begin{array}{c}-0.37^{* * *} \\
(0.00)\end{array}$ & $\begin{array}{c}-0.18^{* *} \\
(0.04)\end{array}$ & $\begin{array}{c}-0.24 * * * \\
(0.01)\end{array}$ & $\begin{array}{c}-0.36^{* * *} \\
(0.00)\end{array}$ & $\begin{array}{c}-0.18^{* * *} \\
(0.00)\end{array}$ \\
\hline Lag Capital stock per emplyed person at current PPPs (2005US\$) (rel to TRD PRT) & $\begin{array}{c}0.11^{* * *} \\
(0.00)\end{array}$ & $\begin{array}{l}-0.02 \\
(0.70)\end{array}$ & $\begin{array}{l}-0.00 \\
(0.94)\end{array}$ & $\begin{array}{c}0.11^{* * *} \\
(0.00)\end{array}$ & $\begin{array}{l}-0.03 \\
(0.38)\end{array}$ \\
\hline Lag Ratio Traded/Non Traded relative to trd part (in logs) & $\begin{array}{c}0.18^{* * *} \\
(0.00)\end{array}$ & $\begin{array}{c}0.08 \\
(0.37)\end{array}$ & $\begin{array}{c}0.09 \\
(0.25)\end{array}$ & $\begin{array}{c}0.18^{* * *} \\
(0.00)\end{array}$ & $\begin{array}{c}0.07 \\
(0.17)\end{array}$ \\
\hline \multicolumn{6}{|l|}{ Structural Fundamentals } \\
\hline Dependency Ratio (rel to TRD PRT) & $\begin{array}{l}0.32 * * \\
(0.02)\end{array}$ & $\begin{array}{l}-0.32 \\
(0.30)\end{array}$ & $\begin{array}{c}0.09 \\
(0.80)\end{array}$ & $\begin{array}{l}0.36 * \\
(0.09)\end{array}$ & $\begin{array}{l}-0.35 \\
(0.17)\end{array}$ \\
\hline Population Growth (rel to TRD PRT) & $\begin{array}{l}2.83^{* *} \\
(0.05)\end{array}$ & $\begin{array}{c}1.83 \\
(0.62)\end{array}$ & $\begin{array}{c}3.05 \\
(0.39)\end{array}$ & $\begin{array}{c}2.57 \\
(0.25)\end{array}$ & $\begin{array}{c}1.90 \\
(0.40)\end{array}$ \\
\hline ICRG-12 (rel to TRD PRT) & $\begin{array}{c}0.67^{* * *} \\
(0.00)\end{array}$ & $\begin{array}{c}0.02 \\
(0.92)\end{array}$ & $\begin{array}{c}0.21 \\
(0.22)\end{array}$ & $\begin{array}{c}0.65^{* * *} \\
(0.00)\end{array}$ & $\begin{array}{c}0.01 \\
(0.95)\end{array}$ \\
\hline Lag of Trade Openness (avg. of exports and imports to GDP) (rel to TRD PRT) & $\begin{array}{c}-0.35^{* * *} \\
(0.00)\end{array}$ & $\begin{array}{l}-0.21 \\
(0.26)\end{array}$ & $\begin{array}{c}-0.27^{* *} \\
(0.05)\end{array}$ & $\begin{array}{c}-0.34^{* * *} \\
(0.00)\end{array}$ & $\begin{array}{l}-0.20^{*} \\
(0.06)\end{array}$ \\
\hline VAT Revenue, $\%$ of GDP (rel to TRD PRT) & $\begin{array}{c}0.47 \\
(0.20)\end{array}$ & $\begin{array}{c}0.72 \\
(0.53)\end{array}$ & $\begin{array}{c}0.20 \\
(0.86)\end{array}$ & $\begin{array}{c}0.66 \\
(0.26)\end{array}$ & $\begin{array}{c}1.49 \\
(0.11)\end{array}$ \\
\hline Share of administered prices in CPI & $\begin{array}{c}-2.81^{* * *} \\
(0.00)\end{array}$ & $\begin{array}{c}0.38 \\
(0.74)\end{array}$ & $\begin{array}{l}-1.05 \\
(0.11)\end{array}$ & $\begin{array}{c}-2.81 * * * \\
(0.00)\end{array}$ & $\begin{array}{c}0.40 \\
(0.52)\end{array}$ \\
\hline \multicolumn{6}{|l|}{ Policy Variables } \\
\hline Real interest rate differential demeaned interacted with $\mathrm{K}$ openness (rel to TRD & $\begin{array}{l}0.59^{* *} \\
(0.02)\end{array}$ & $\begin{array}{c}0.59 \\
(0.14)\end{array}$ & $\begin{array}{c}0.47 \\
(0.24)\end{array}$ & $\begin{array}{l}0.59 * \\
(0.08)\end{array}$ & $\begin{array}{l}0.56 * * \\
(0.02)\end{array}$ \\
\hline Lag of Public health exp. (The new series) (rel to TRD PRT) & $\begin{array}{c}4.25 * * * \\
(0.00)\end{array}$ & $\begin{array}{c}1.51 \\
(0.28)\end{array}$ & $\begin{array}{l}3.32 * * \\
(0.03)\end{array}$ & $\begin{array}{c}4.20 * * * \\
(0.00)\end{array}$ & $\begin{array}{l}1.46^{*} \\
(0.07)\end{array}$ \\
\hline Change in reserves to GDP * capital controls (The new series) (rel to TRD PRT) & $\begin{array}{c}-1.11^{* *} \\
(0.02)\end{array}$ & $\begin{array}{l}-0.74 * \\
(0.07)\end{array}$ & $\begin{array}{l}-0.63 \\
(0.13)\end{array}$ & $\begin{array}{l}-3.56^{*} \\
(0.06)\end{array}$ & $\begin{array}{c}-3.05^{* *} \\
(0.02)\end{array}$ \\
\hline Private credit/GDP gap (Detrended) (rel to TRD PRT) & $\begin{array}{c}0.07 \\
(0.14)\end{array}$ & $\begin{array}{l}0.17^{* *} \\
(0.05)\end{array}$ & $\begin{array}{l}0.14^{*} \\
(0.10)\end{array}$ & $\begin{array}{c}0.03 \\
(0.65)\end{array}$ & $\begin{array}{c}0.12 * * \\
(0.03)\end{array}$ \\
\hline Lag of VIX * capital account openness & $\begin{array}{l}-0.17^{*} \\
(0.08)\end{array}$ & $\begin{array}{c}-0.19 * * \\
(0.02)\end{array}$ & $\begin{array}{c}-0.21 * * * \\
(0.01)\end{array}$ & $\begin{array}{l}-0.15 \\
(0.25)\end{array}$ & $\begin{array}{c}-0.17^{* *} \\
(0.04)\end{array}$ \\
\hline Lag of VIX * capital account openness *share of own currency in global reserve & $\begin{array}{l}0.84 * * \\
(0.04)\end{array}$ & $\begin{array}{c}0.65^{* * *} \\
(0.01)\end{array}$ & $\begin{array}{c}0.73^{* * *} \\
(0.01)\end{array}$ & $\begin{array}{c}0.83 \\
(0.13)\end{array}$ & $\begin{array}{l}0.66^{*} \\
(0.06)\end{array}$ \\
\hline Constant & $\begin{array}{c}0.19^{* * *} \\
(0.00)\end{array}$ & $\begin{array}{l}-0.03 \\
(0.57)\end{array}$ & $\begin{array}{l}0.12 * * \\
(0.02)\end{array}$ & $\begin{array}{c}0.19 * * * \\
(0.00)\end{array}$ & $\begin{array}{c}0.27^{* * *} \\
(0.00)\end{array}$ \\
\hline Observations & 990 & 990 & 990 & 990 & 990 \\
\hline RMSE & 0.1430 & 0.08912 & 0.1006 & 0.1456 & 0.09410 \\
\hline Number of Countries & 39 & 39 & 39 & 39 & 39 \\
\hline Within R-sq & 0.11 & 0.32 & 0.26 & 0.11 & 0.01 \\
\hline Between R-sq & 0.96 & 0.60 & 0.88 & 0.96 & 0.55 \\
\hline Overall R-sq & 0.90 & 0.55 & 0.84 & 0.90 & 0.96 \\
\hline
\end{tabular}

Robust pval in parentheses

$* * * p<0.01, * * p<0.05, * p<0.1$ 
Table 5: Benchmark versus alternative LHS variables, based on different XS dimension from ICP 2011 and PWT 9.0 (same estimation method, IV-REG)

\begin{tabular}{|c|c|c|c|c|c|}
\hline & $\begin{array}{l}\text { INS-CPI } \\
\text { ICP-2011 P }\end{array}$ & $\begin{array}{l}\text { INS-CPI } \\
\text { PWT9 P }\end{array}$ & $\begin{array}{l}\text { INS-CPI } \\
\text { ICP-2011 PC }\end{array}$ & $\begin{array}{l}\text { INS-CPI } \\
\text { PWT9 PC }\end{array}$ & $\begin{array}{l}\text { INS-CPI } \\
\text { PWT9 PA }\end{array}$ \\
\hline VARIABLES & $\begin{array}{l}\text { Benchmark } \\
\text { ICP GDP } \\
\text { Based }\end{array}$ & $\begin{array}{c}1 \\
\text { PWT 9.0 } \\
\text { GDP Based }\end{array}$ & $\begin{array}{c}2 \\
\text { ICP Consum. } \\
\text { Based }\end{array}$ & $\begin{array}{c}3 \\
\text { PWT } 9.0 \\
\text { Total } \\
\text { Consum. } \\
\end{array}$ & $\begin{array}{c}4 \\
\text { PWT 9.0 } \\
\text { Absorption }\end{array}$ \\
\hline \multicolumn{6}{|l|}{ Cyclical Factors } \\
\hline $\begin{array}{l}\text { Log Commodity ToT (43) levels in } 2011 \text { vs trading } \\
\text { partner }\end{array}$ & $\begin{array}{c}0.06 * * * \\
(0.00)\end{array}$ & $\begin{array}{c}0.12^{* * *} \\
(0.00)\end{array}$ & $\begin{array}{c}0.07 * * * \\
(0.00)\end{array}$ & $\begin{array}{c}0.07^{* * *} \\
(0.00)\end{array}$ & $\begin{array}{c}0.06 * * * \\
(0.00)\end{array}$ \\
\hline \multicolumn{6}{|l|}{ Macroeconomic Fundamentals } \\
\hline NFA/GDP & $\begin{array}{c}0.06 * * * \\
(0.00)\end{array}$ & $\begin{array}{c}0.02 \\
(0.30)\end{array}$ & $\begin{array}{c}0.06^{* * *} \\
(0.00)\end{array}$ & $\begin{array}{c}0.07^{* * *} \\
(0.00)\end{array}$ & $\begin{array}{c}0.05^{* * *} \\
(0.01)\end{array}$ \\
\hline Lag Demeaned PPPGDP/Top3(PPP)] & $\begin{array}{c}0.17^{* * *} \\
(0.00)\end{array}$ & $\begin{array}{c}0.12^{* * *} \\
(0.00)\end{array}$ & $\begin{array}{c}0.22^{* * *} \\
(0.00)\end{array}$ & $\begin{array}{c}0.22^{* * *} \\
(0.00)\end{array}$ & $\begin{array}{c}0.19 * * * \\
(0.00)\end{array}$ \\
\hline $\begin{array}{l}\text { Expected GDP growth of medium-term( } 5 \text { years out), } \\
\text { WEO project (rel to TRD PRT) }\end{array}$ & $\begin{array}{l}1.96 * * \\
(0.05)\end{array}$ & $\begin{array}{l}1.95 * \\
(0.05)\end{array}$ & $\begin{array}{l}2.17^{* *} \\
(0.04)\end{array}$ & $\begin{array}{c}1.70 \\
(0.11)\end{array}$ & $\begin{array}{l}1.83^{*} \\
(0.06)\end{array}$ \\
\hline $\begin{array}{l}\text { Share of the country's currency held as FX reserve by } \\
\text { central banks worldwide }\end{array}$ & $\begin{array}{c}-0.36 * * * \\
(0.00)\end{array}$ & $\begin{array}{c}-0.28 * * * \\
(0.00)\end{array}$ & $\begin{array}{c}-0.38 * * * \\
(0.00)\end{array}$ & $\begin{array}{c}-0.34^{* * *} \\
(0.00)\end{array}$ & $\begin{array}{c}-0.37 * * * \\
(0.00)\end{array}$ \\
\hline $\begin{array}{l}\text { Lag Capital stock per emplyed person at current } \\
\text { PPPs (2005US\$) (rel to TRD PRT) }\end{array}$ & $0.11 * * *$ & $0.14^{* * *}$ & $0.09 * * *$ & $0.08^{* * *}$ & $0.09 * * *$ \\
\hline $\begin{array}{l}\text { Lag Ratio Traded/Non Traded relative to trd part (in } \\
\text { logs) }\end{array}$ & $\begin{array}{c}0.18^{* * *} \\
(0.00)\end{array}$ & $\begin{array}{c}0.18^{* * *} \\
(0.00)\end{array}$ & $\begin{array}{l}0.20 * * * \\
(0.00)\end{array}$ & $\begin{array}{c}0.19 * * * \\
(0.00)\end{array}$ & $\begin{array}{c}0.18^{* * *} \\
(0.00)\end{array}$ \\
\hline Structural Factors & & & & & \\
\hline Dependency Ratio (rel to TRD PRT) & $\begin{array}{l}0.36^{*} \\
(0.09)\end{array}$ & $\begin{array}{c}0.68 * * * \\
(0.00)\end{array}$ & $\begin{array}{l}0.50^{* *} \\
(0.03)\end{array}$ & $\begin{array}{l}0.44^{*} \\
(0.05)\end{array}$ & $\begin{array}{l}0.39 * \\
(0.07)\end{array}$ \\
\hline Population Growth (rel to TRD PRT) & $\begin{array}{c}2.57 \\
(0.25)\end{array}$ & $\begin{array}{c}3.72 \\
(0.11)\end{array}$ & $\begin{array}{c}3.85 \\
(0.12)\end{array}$ & $\begin{array}{c}4.03 \\
(0.11)\end{array}$ & $\begin{array}{c}3.38 \\
(0.13)\end{array}$ \\
\hline ICRG-12 (rel to TRD PRT) & $\begin{array}{c}0.65 * * * \\
(0.00)\end{array}$ & $\begin{array}{c}0.58^{* * *} \\
(0.00)\end{array}$ & $\begin{array}{c}0.63^{* * *} \\
(0.00)\end{array}$ & $\begin{array}{c}0.62^{* * *} \\
(0.00)\end{array}$ & $\begin{array}{c}0.64 * * * \\
(0.00)\end{array}$ \\
\hline $\begin{array}{l}\text { Lag of Trade Openness (avg. of exports and imports } \\
\text { to GDP) (rel to TRD PRT) }\end{array}$ & $\begin{array}{c}-0.34 * * * \\
(0.00)\end{array}$ & $\begin{array}{c}-0.26 * * * \\
(0.00)\end{array}$ & $\begin{array}{c}-0.28 * * * \\
(0.00)\end{array}$ & $\begin{array}{c}-0.28 * * * \\
(0.00)\end{array}$ & $\begin{array}{c}-0.35^{* * *} \\
(0.00)\end{array}$ \\
\hline VAT Revenue, $\%$ of GDP (rel to TRD PRT) & $\begin{array}{c}0.66 \\
(0.26)\end{array}$ & $\begin{array}{c}1.61^{* * *} \\
(0.01)\end{array}$ & $\begin{array}{c}0.87 \\
(0.17)\end{array}$ & $\begin{array}{c}1.00 \\
(0.11)\end{array}$ & $\begin{array}{c}0.60 \\
(0.30)\end{array}$ \\
\hline Share of administered prices in CPI & $\begin{array}{c}-2.81 * * * \\
(0.00)\end{array}$ & $\begin{array}{c}-2.71 * * * \\
(0.00)\end{array}$ & $\begin{array}{c}-3.23^{* * *} \\
(0.00)\end{array}$ & $\begin{array}{c}-3.34^{* * *} \\
(0.00)\end{array}$ & $\begin{array}{c}-2.89 * * * \\
(0.00)\end{array}$ \\
\hline Policy Variables & & & & & \\
\hline $\begin{array}{l}\text { Real interest rate differential demeaned interacted } \\
\text { with } \mathrm{K} \text { openness (rel to TRD }\end{array}$ & $\begin{array}{l}0.59 * \\
(0.08)\end{array}$ & $\begin{array}{l}0.63 * \\
(0.07)\end{array}$ & $\begin{array}{l}0.25 \\
(0.55)\end{array}$ & $\begin{array}{l}0.29 \\
(0.47)\end{array}$ & $\begin{array}{l}0.51 \\
(0.13)\end{array}$ \\
\hline $\begin{array}{l}\text { Lag of Public health exp. (The new series) (rel to TRD } \\
\text { PRT) }\end{array}$ & $\begin{array}{c}4.20 * * * \\
(0.00)\end{array}$ & $\begin{array}{c}3.27^{* * *} \\
(0.00)\end{array}$ & $\begin{array}{c}3.86 * * * \\
(0.00)\end{array}$ & $\begin{array}{c}4.05^{* * *} \\
(0.00)\end{array}$ & $\begin{array}{c}4.32 * * * \\
(0.00)\end{array}$ \\
\hline $\begin{array}{l}\text { Change in reserves to GDP * capital controls (The } \\
\text { new series) (rel to TRD PRT) }\end{array}$ & $\begin{array}{l}-3.56 * \\
(0.06)\end{array}$ & $\begin{array}{l}-3.21 * \\
(0.06)\end{array}$ & $\begin{array}{l}-3.85 * \\
(0.07)\end{array}$ & $\begin{array}{l}-3.58^{*} \\
(0.09)\end{array}$ & $\begin{array}{l}-3.34 * \\
(0.08)\end{array}$ \\
\hline Private credit/GDP gap (Detrended) (rel to TRD PRT) & $\begin{array}{c}0.03 \\
(0.65)\end{array}$ & $\begin{array}{c}0.02 \\
(0.78)\end{array}$ & $\begin{array}{c}0.03 \\
(0.73)\end{array}$ & $\begin{array}{c}0.02 \\
(0.81)\end{array}$ & $\begin{array}{c}0.02 \\
(0.78)\end{array}$ \\
\hline Lag of VIX * capital account openness & $\begin{array}{l}-0.15 \\
(0.25)\end{array}$ & $\begin{array}{l}-0.16 \\
(0.22)\end{array}$ & $\begin{array}{l}-0.15 \\
(0.30)\end{array}$ & $\begin{array}{l}-0.17 \\
(0.23)\end{array}$ & $\begin{array}{l}-0.15 \\
(0.24)\end{array}$ \\
\hline $\begin{array}{l}\text { Lag of VIX * capital account openness *share of own } \\
\text { currency in global reserve }\end{array}$ & $\begin{array}{c}0.83 \\
(0.13)\end{array}$ & $\begin{array}{l}0.87^{*} \\
(0.10)\end{array}$ & $\begin{array}{c}0.86 \\
(0.14)\end{array}$ & $\begin{array}{c}0.90 \\
(0.12)\end{array}$ & $\begin{array}{c}0.83 \\
(0.13)\end{array}$ \\
\hline Constant & $\begin{array}{l}0.19 * * * \\
(0.00)\end{array}$ & $\begin{array}{l}0.15^{* * *} \\
(0.00)\end{array}$ & $\begin{array}{l}0.21^{* * *} \\
(0.00)\end{array}$ & $\begin{array}{c}0.20 * * * \\
(0.00)\end{array}$ & $\begin{array}{c}0.19 * * * \\
(0.00)\end{array}$ \\
\hline Observations & 990 & 990 & 990 & 990 & 990 \\
\hline RMSE & 0.1456 & 0.1468 & 0.1582 & 0.1573 & 0.1447 \\
\hline Number of Countries & 39 & 39 & 39 & 39 & 39 \\
\hline Within R-sq & 0.11 & 0.11 & 0.11 & 0.11 & 0.11 \\
\hline Between R-sq & 0.96 & 0.96 & 0.95 & 0.95 & 0.96 \\
\hline Overall R-sq & 0.90 & 0.89 & 0.89 & 0.89 & 0.90 \\
\hline
\end{tabular}

Robust pval in parentheses

${ }^{* * *} p<0.01,{ }^{* *} p<0.05, * p<0.1$ 
Table 6: Benchmark versus alternative LHS variables based on REER Index constructed with GDP Deflator (WEO) and adjusting the level with the XS dimension of ICP 2011 and PWT 9.0 (same estimation method, IV-REG)

\begin{tabular}{|c|c|c|c|c|c|c|}
\hline $\begin{array}{l}\text { TS: } \\
\text { XS: }\end{array}$ & $\begin{array}{l}\text { INS-CPI } \\
\text { ICP-2011 P }\end{array}$ & $\begin{array}{l}\text { WEO GDP Defl. } \\
\text { ICP-2011 P }\end{array}$ & $\begin{array}{l}\text { WEO GDP Defl. } \\
\text { PWT9 P }\end{array}$ & $\begin{array}{l}\text { WEO GDP Defl. } \\
\text { ICP-2011 PC }\end{array}$ & $\begin{array}{l}\text { WEO GDP Defl. } \\
\text { PWT9 PC }\end{array}$ & $\begin{array}{l}\text { WEO GDP Defl } \\
\text { PWT9 PA }\end{array}$ \\
\hline & Benchmark & 1 & 2 & 3 & 4 & 5 \\
\hline VARIABLES & $\begin{array}{l}\text { ICP GDP } \\
\text { Based }\end{array}$ & ICP GDP Based & $\begin{array}{l}\text { PWT 9.0 GDP } \\
\text { Based }\end{array}$ & $\begin{array}{l}\text { ICP Consum. } \\
\text { Based }\end{array}$ & $\begin{array}{l}\text { PWT } 9.0 \text { Total } \\
\text { Consum. }\end{array}$ & $\begin{array}{l}\text { PWT } 9.0 \\
\text { Absorption }\end{array}$ \\
\hline \multicolumn{7}{|l|}{ Cyclical Factors } \\
\hline \multirow{2}{*}{$\begin{array}{l}\text { Log Commodity ToT (43) levels in } 2011 \text { vs trading } \\
\text { partner }\end{array}$} & $0.06 * * *$ & $0.20^{* * *}$ & $0.26^{* * *}$ & $0.22^{* * *}$ & $0.21^{* * *}$ & $0.20^{* * *}$ \\
\hline & $(0.00)$ & $(0.00)$ & $(0.00)$ & $(0.00)$ & $(0.00)$ & $(0.00)$ \\
\hline \multicolumn{7}{|l|}{ Macroeconomic Fundamentals } \\
\hline NFA/GDP & $\begin{array}{c}0.06 * * * \\
(0.00)\end{array}$ & $\begin{array}{c}0.08^{* * *} \\
(0.00)\end{array}$ & $\begin{array}{l}0.04 * * \\
(0.04)\end{array}$ & $\begin{array}{c}0.08^{* * *} \\
(0.00)\end{array}$ & $\begin{array}{c}0.09 * * * \\
(0.00)\end{array}$ & $\begin{array}{c}0.07^{* * *} \\
(0.00)\end{array}$ \\
\hline Lag Demeaned PPPGDP/Top3(PPP)] & $\begin{array}{l}0.17^{* * *} \\
(0.00)\end{array}$ & $\begin{array}{c}0.18^{* * *} \\
(0.00)\end{array}$ & $\begin{array}{c}0.13^{* * *} \\
(0.00)\end{array}$ & $\begin{array}{c}0.23^{* * *} \\
(0.00)\end{array}$ & $\begin{array}{c}0.23 * * * \\
(0.00)\end{array}$ & $\begin{array}{c}0.20^{* * *} \\
(0.00)\end{array}$ \\
\hline \multirow[t]{2}{*}{$\begin{array}{l}\text { Expected GDP growth of medium-term( } 5 \text { years out), } \\
\text { WEO project (rel to TRD PRT) }\end{array}$} & $1.96 * *$ & $2.52^{* *}$ & $2.52^{* *}$ & $2.74 * *$ & $2.27 * *$ & $2.40^{* *}$ \\
\hline & $(0.05)$ & $(0.02)$ & $(0.01)$ & $(0.01)$ & $(0.04)$ & $(0.02)$ \\
\hline \multirow{2}{*}{$\begin{array}{l}\text { Share of the country's currency held as FX reserve by } \\
\text { central banks worldwide }\end{array}$} & $-0.36 * * *$ & $-0.30 * * *$ & $-0.22^{* * *}$ & $-0.32^{* * *}$ & $-0.28^{* * *}$ & $-0.31^{* * *}$ \\
\hline & $(0.00)$ & $(0.00)$ & $(0.00)$ & $(0.00)$ & $(0.00)$ & $(0.00)$ \\
\hline \multirow{2}{*}{$\begin{array}{l}\text { Lag Capital stock per emplyed person at current } \\
\text { PPPs (2005US\$) (rel to TRD PRT) }\end{array}$} & $0.11^{* * *}$ & $0.13^{* * *}$ & $0.16^{* * *}$ & $0.11^{* * *}$ & $0.10^{* * *}$ & $0.11^{* * *}$ \\
\hline & $(0.00)$ & $(0.00)$ & $(0.00)$ & $(0.00)$ & $(0.00)$ & $(0.00)$ \\
\hline \multirow{2}{*}{$\begin{array}{l}\text { Lag Ratio Traded/Non Traded relative to trd part (in } \\
\text { logs) }\end{array}$} & $0.18^{* * *}$ & $0.15^{* * *}$ & $0.15^{* * *}$ & $0.17^{* * *}$ & $0.16^{* * *}$ & $0.15^{* * *}$ \\
\hline & $(0.00)$ & $(0.00)$ & $(0.00)$ & $(0.00)$ & $(0.00)$ & $(0.00)$ \\
\hline \multicolumn{7}{|l|}{ Structural Factors } \\
\hline \multirow[t]{2}{*}{ Dependency Ratio (rel to TRD PRT) } & $0.36^{*}$ & 0.25 & $0.56^{* *}$ & $0.38^{*}$ & 0.33 & 0.28 \\
\hline & $(0.09)$ & $(0.24)$ & $(0.01)$ & $(0.09)$ & $(0.14)$ & $(0.20)$ \\
\hline \multirow[t]{2}{*}{ Population Growth (rel to TRD PRT) } & 2.57 & 1.26 & 2.42 & 2.55 & 2.73 & 2.08 \\
\hline & $(0.25)$ & $(0.56)$ & $(0.27)$ & $(0.28)$ & $(0.25)$ & $(0.33)$ \\
\hline \multirow[t]{2}{*}{ ICRG-12 (rel to TRD PRT) } & $0.65 * * *$ & $0.71^{* * *}$ & $0.64^{* * *}$ & $0.69 * * *$ & $0.68 * * *$ & $0.70^{* * *}$ \\
\hline & $(0.00)$ & $(0.00)$ & $(0.00)$ & $(0.00)$ & $(0.00)$ & $(0.00)$ \\
\hline \multirow{2}{*}{$\begin{array}{l}\text { Lag of Trade Openness (avg. of exports and imports } \\
\text { to GDP) (rel to TRD PRT) }\end{array}$} & $-0.34 * * *$ & $-0.37^{* * *}$ & $-0.30 * * *$ & $-0.31^{* * *}$ & $-0.31^{* * *}$ & $-0.38^{* * *}$ \\
\hline & $(0.00)$ & $(0.00)$ & $(0.00)$ & $(0.00)$ & $(0.00)$ & $(0.00)$ \\
\hline \multirow[t]{2}{*}{ VAT Revenue, $\%$ of GDP (rel to TRD PRT) } & 0.66 & 0.95 & $1.90^{* * *}$ & $1.16^{*}$ & $1.29 * *$ & 0.89 \\
\hline & $(0.26)$ & $(0.12)$ & $(0.00)$ & $(0.07)$ & $(0.04)$ & $(0.14)$ \\
\hline \multirow[t]{2}{*}{ Share of administered prices in CPI } & $-2.81 * * *$ & $-2.47^{* * *}$ & $-2.37 * * *$ & $-2.90 * * *$ & $-3.00 * * *$ & $-2.55^{* * *}$ \\
\hline & $(0.00)$ & $(0.00)$ & $(0.00)$ & $(0.00)$ & $(0.00)$ & $(0.00)$ \\
\hline \multicolumn{7}{|l|}{ Policy Variables } \\
\hline \multirow{2}{*}{$\begin{array}{l}\text { Real interest rate differential demeaned interacted } \\
\text { with K openness (rel to TRD }\end{array}$} & $0.59 *$ & $0.80^{* *}$ & $0.84^{* *}$ & 0.46 & 0.50 & $0.73^{* *}$ \\
\hline & $(0.08)$ & $(0.03)$ & $(0.02)$ & $(0.28)$ & $(0.23)$ & $(0.05)$ \\
\hline \multirow{2}{*}{$\begin{array}{l}\text { Lag of Public health exp. (The new series) (rel to TRD } \\
\text { PRT) }\end{array}$} & $4.20^{* * *}$ & $3.85^{* * *}$ & $2.92^{* * *}$ & $3.51^{* * *}$ & $3.71^{* * *}$ & $3.97^{* * *}$ \\
\hline & $(0.00)$ & $(0.00)$ & $(0.00)$ & $(0.00)$ & $(0.00)$ & $(0.00)$ \\
\hline \multirow{2}{*}{$\begin{array}{l}\text { Change in reserves to GDP * capital controls (The } \\
\text { new series) (rel to TRD PRT) }\end{array}$} & $-3.56^{*}$ & $-8.02 * * *$ & $-7.69 * * *$ & $-8.32 * * *$ & $-8.06 * * *$ & $-7.82^{* * *}$ \\
\hline & $(0.06)$ & $(0.00)$ & $(0.00)$ & $(0.00)$ & $(0.00)$ & $(0.00)$ \\
\hline Private credit/GDP gap (Detrended) (rel to TRD PRT) & 0.03 & -0.03 & -0.04 & -0.03 & -0.04 & -0.04 \\
\hline & $(0.65)$ & $(0.71)$ & $(0.58)$ & $(0.70)$ & $(0.63)$ & $(0.60)$ \\
\hline Lag of VIX* capital account openness & -0.15 & -0.06 & -0.07 & -0.06 & -0.08 & -0.06 \\
\hline & $(0.25)$ & $(0.66)$ & $(0.62)$ & $(0.68)$ & $(0.58)$ & $(0.64)$ \\
\hline Lag of VIX * capital account openness *share of own & 0.83 & 0.49 & 0.53 & 0.53 & 0.57 & 0.49 \\
\hline & $(0.13)$ & $(0.39)$ & $(0.33)$ & $(0.38)$ & $(0.35)$ & $(0.39)$ \\
\hline Constant & $0.19^{* * *}$ & $0.17^{* * *}$ & $0.13^{* * *}$ & $0.19^{* * *}$ & $0.18^{* * *}$ & $0.17^{* * *}$ \\
\hline & $(0.00)$ & $(0.00)$ & $(0.00)$ & $(0.00)$ & $(0.00)$ & $(0.00)$ \\
\hline Observations & 990 & 990 & 990 & 990 & 990 & 990 \\
\hline RMSE & 0.1456 & 0.1606 & 0.1618 & 0.1709 & 0.1688 & 0.1597 \\
\hline Number of Countries & 39 & 39 & 39 & 39 & 39 & 39 \\
\hline Within R-sq & 0.11 & 0.29 & 0.31 & 0.29 & 0.30 & 0.29 \\
\hline Between R-sq & 0.96 & 0.96 & 0.96 & 0.96 & 0.96 & 0.96 \\
\hline Overall R-sq & 0.90 & 0.88 & 0.88 & 0.88 & 0.89 & 0.88 \\
\hline
\end{tabular}

Robust pval in parentheses

${ }^{* * *} p<0.01,{ }^{* *} p<0.05,{ }^{*} p<0.1$ 
Table 7: Benchmark versus alternative LHS variables based on full panel (XS and TS) dimension of PWT 9.0 (same estimation method, IV-REG)

\begin{tabular}{|c|c|c|c|c|}
\hline $\begin{array}{l}\text { TS: } 1 \\
\mathrm{XS}: 1\end{array}$ & $\begin{array}{l}\text { INS-CPI } \\
\text { ICP-2011 P }\end{array}$ & PWT9 P & PWT9 PC & PWT9 PA \\
\hline VARIABLES & $\begin{array}{l}\text { Benchmark } \\
\text { ICP GDP } \\
\text { Based }\end{array}$ & $\begin{array}{c}1 \\
\text { PWT } 9.0 \\
\text { GDP Based }\end{array}$ & $\begin{array}{c}2 \\
\text { PWT } 9.0 \\
\text { Total } \\
\text { Consum. }\end{array}$ & $\begin{array}{c}3 \\
\text { PWT 9.0 } \\
\text { Absorption }\end{array}$ \\
\hline \multicolumn{5}{|l|}{ Cyclical Factors } \\
\hline $\begin{array}{l}\text { Log Commodity ToT (43) levels in } 2011 \text { vs trading } \\
\text { partner }\end{array}$ & $\begin{array}{r}0.06^{* * *} \\
(0.00)\end{array}$ & $\begin{array}{r}0.12^{* * *} \\
(0.00)\end{array}$ & $\begin{array}{r}0.10 * * * \\
(0.00)\end{array}$ & $\begin{array}{r}0.10^{* * *} \\
(0.00)\end{array}$ \\
\hline \multicolumn{5}{|l|}{ Macroeconomic Fundamentals } \\
\hline NFA/GDP & $\begin{array}{r}0.06^{* * *} \\
(0.00)\end{array}$ & $\begin{array}{r}0.07^{* * *} \\
(0.00)\end{array}$ & $\begin{array}{r}0.11^{* * *} \\
(0.00)\end{array}$ & $\begin{array}{r}0.10^{* * *} \\
(0.00)\end{array}$ \\
\hline Lag Demeaned PPPGDP/Top3(PPP)] & $\begin{array}{r}0.17^{* * *} \\
(0.00)\end{array}$ & $\begin{array}{r}0.20^{* * *} \\
(0.00)\end{array}$ & $\begin{array}{r}0.26^{* * *} \\
(0.00)\end{array}$ & $\begin{array}{r}0.25 * * * \\
(0.00)\end{array}$ \\
\hline $\begin{array}{l}\text { Expected GDP growth of medium-term( } 5 \text { years out), } \\
\text { WEO project (rel to TRD PRT) }\end{array}$ & $1.96 * *$ & $\begin{array}{r}1.32 \\
(0.21)\end{array}$ & $\begin{array}{r}1.63 \\
(0.19)\end{array}$ & $\begin{array}{r}1.54 \\
(0.15)\end{array}$ \\
\hline $\begin{array}{l}\text { Share of the country's currency held as FX reserve by } \\
\text { central banks worldwide }\end{array}$ & $\begin{array}{r}-0.36 * * * \\
(0.00)\end{array}$ & $\begin{array}{r}-0.20^{* * *} \\
(0.01)\end{array}$ & $\begin{array}{r}-0.25^{* * *} \\
(0.00)\end{array}$ & $\begin{array}{r}-0.24 * * * \\
(0.00)\end{array}$ \\
\hline $\begin{array}{l}\text { Lag Capital stock per emplyed person at current } \\
\text { PPPs (2005US\$) (rel to TRD PRT) }\end{array}$ & $\begin{array}{r}0.11^{* * *} \\
(0.00)\end{array}$ & $\begin{array}{r}0.14^{* * *} \\
(0.00)\end{array}$ & $\begin{array}{r}0.16 * * * \\
(0.00)\end{array}$ & $\begin{array}{r}0.11^{* * *} \\
(0.00)\end{array}$ \\
\hline $\begin{array}{l}\text { Lag Ratio Traded/Non Traded relative to trd part (in } \\
\text { logs) }\end{array}$ & $\begin{array}{r}0.18^{* * *} \\
(0.00)\end{array}$ & $\begin{array}{r}0.11^{* * *} \\
(0.01)\end{array}$ & $\begin{array}{r}0.07 \\
(0.15)\end{array}$ & $\begin{array}{r}0.09 * * \\
(0.03)\end{array}$ \\
\hline Structural Factors & & & & \\
\hline Dependency Ratio (rel to TRD PRT) & $\begin{array}{l}0.36 * \\
(0.09)\end{array}$ & $\begin{array}{l}0.39 * \\
(0.06)\end{array}$ & $\begin{array}{r}0.00 \\
(0.99)\end{array}$ & $\begin{array}{r}0.15 \\
(0.47)\end{array}$ \\
\hline Population Growth (rel to TRD PRT) & $\begin{array}{r}2.57 \\
(0.25)\end{array}$ & $\begin{array}{r}0.47 \\
(0.84)\end{array}$ & $\begin{array}{r}0.60 \\
(0.83)\end{array}$ & $\begin{array}{r}1.02 \\
(0.67)\end{array}$ \\
\hline ICRG-12 (rel to TRD PRT) & $\begin{array}{r}0.65^{* * *} \\
(0.00)\end{array}$ & $\begin{array}{r}0.31 * * \\
(0.04)\end{array}$ & $\begin{array}{r}0.38^{* *} \\
(0.03)\end{array}$ & $\begin{array}{r}0.39 * * * \\
(0.01)\end{array}$ \\
\hline Lag of Trade Openness (avg. of exports and imports & $\begin{array}{r}-0.34 * * * \\
(0.00)\end{array}$ & $\begin{array}{r}-0.24 * * * \\
(0.00)\end{array}$ & $\begin{array}{r}-0.27^{* * *} \\
(0.00)\end{array}$ & $\begin{array}{r}-0.31^{* * *} \\
(0.00)\end{array}$ \\
\hline VAT Revenue, $\%$ of GDP (rel to TRD PRT) & $\begin{array}{r}0.66 \\
(0.26)\end{array}$ & $\begin{array}{r}2.13^{* * *} \\
(0.00)\end{array}$ & $\begin{array}{r}2.08^{* * *} \\
(0.01)\end{array}$ & $\begin{array}{r}1.71^{* *} \\
(0.01)\end{array}$ \\
\hline Share of administered prices in CPI & $\begin{array}{r}-2.81 * * * \\
(0.00)\end{array}$ & $\begin{array}{r}-2.22 * * * \\
(0.00)\end{array}$ & $\begin{array}{r}-2.87^{* * *} \\
(0.00)\end{array}$ & $\begin{array}{r}-2.32 * * * \\
(0.00)\end{array}$ \\
\hline Policy Variables & & & & \\
\hline $\begin{array}{l}\text { Real interest rate differential demeaned interacted } \\
\text { with K openness (rel to TRD }\end{array}$ & $\begin{array}{l}0.59 * \\
(0.08)\end{array}$ & $\begin{array}{r}0.44 \\
(0.21)\end{array}$ & $\begin{array}{r}0.43 \\
(0.31)\end{array}$ & $\begin{array}{r}0.52 \\
(0.15)\end{array}$ \\
\hline $\begin{array}{l}\text { Lag of Public health exp. (The new series) (rel to TRD } \\
\text { PRT) }\end{array}$ & $4.20^{* * *}$ & $1.62^{* *}$ & $2.22^{* *}$ & $2.51^{* * *}$ \\
\hline & $(0.00)$ & $(0.04)$ & $(0.01)$ & $(0.00)$ \\
\hline $\begin{array}{l}\text { Change in reserves to GDP * capital controls (The } \\
\text { new series) (rel to TRD PRT) }\end{array}$ & $\begin{array}{l}-3.56 * \\
(0.06)\end{array}$ & $\begin{array}{r}-8.91^{* * *} \\
(0.00)\end{array}$ & $\begin{array}{r}-11.12^{* * *} \\
(0.00)\end{array}$ & $\begin{array}{r}-9.35^{* * *} \\
(0.00)\end{array}$ \\
\hline Private credit/GDP gap (Detrended) (rel to TRD PRT) & $\begin{array}{r}0.03 \\
(0.65)\end{array}$ & $\begin{array}{r}-0.10 \\
(0.23)\end{array}$ & $\begin{array}{r}-0.11 \\
(0.26)\end{array}$ & $\begin{array}{r}-0.09 \\
(0.29)\end{array}$ \\
\hline Lag of VIX * capital account openness & $\begin{array}{r}-0.15 \\
(0.25)\end{array}$ & $\begin{array}{r}-0.02 \\
(0.91)\end{array}$ & $\begin{array}{r}-0.00 \\
(0.98)\end{array}$ & $\begin{array}{r}-0.00 \\
(0.99)\end{array}$ \\
\hline $\begin{array}{l}\text { Lag of VIX * capital account openness *share of own } \\
\text { currency in global reserve }\end{array}$ & $\begin{array}{r}0.83 \\
(0.13)\end{array}$ & $\begin{array}{r}0.40 \\
(0.48)\end{array}$ & $\begin{array}{r}0.45 \\
(0.47)\end{array}$ & $\begin{array}{r}0.43 \\
(0.45)\end{array}$ \\
\hline Constant & $\begin{array}{r}0.19 * * * \\
(0.00)\end{array}$ & $\begin{array}{r}0.09 * * * \\
(0.00)\end{array}$ & $\begin{array}{r}0.12^{* * *} \\
(0.00)\end{array}$ & $\begin{array}{r}0.12^{* * *} \\
(0.00)\end{array}$ \\
\hline Observations & 990 & 913 & 913 & 913 \\
\hline RMSE & 0.1456 & 0.1610 & 0.1813 & 0.1613 \\
\hline Number of Countries & 39 & 39 & 39 & 39 \\
\hline Within R2 & 0.11 & 0.25 & 0.26 & 0.26 \\
\hline Between R2 & 0.96 & 0.97 & 0.96 & 0.97 \\
\hline Overall R2 & 0.90 & 0.87 & 0.87 & 0.87 \\
\hline
\end{tabular}

\section{CInternational Monetary Fund. Not for Redistribution}


Figure 1: Level REER and Output per worker relative to top 3 economies

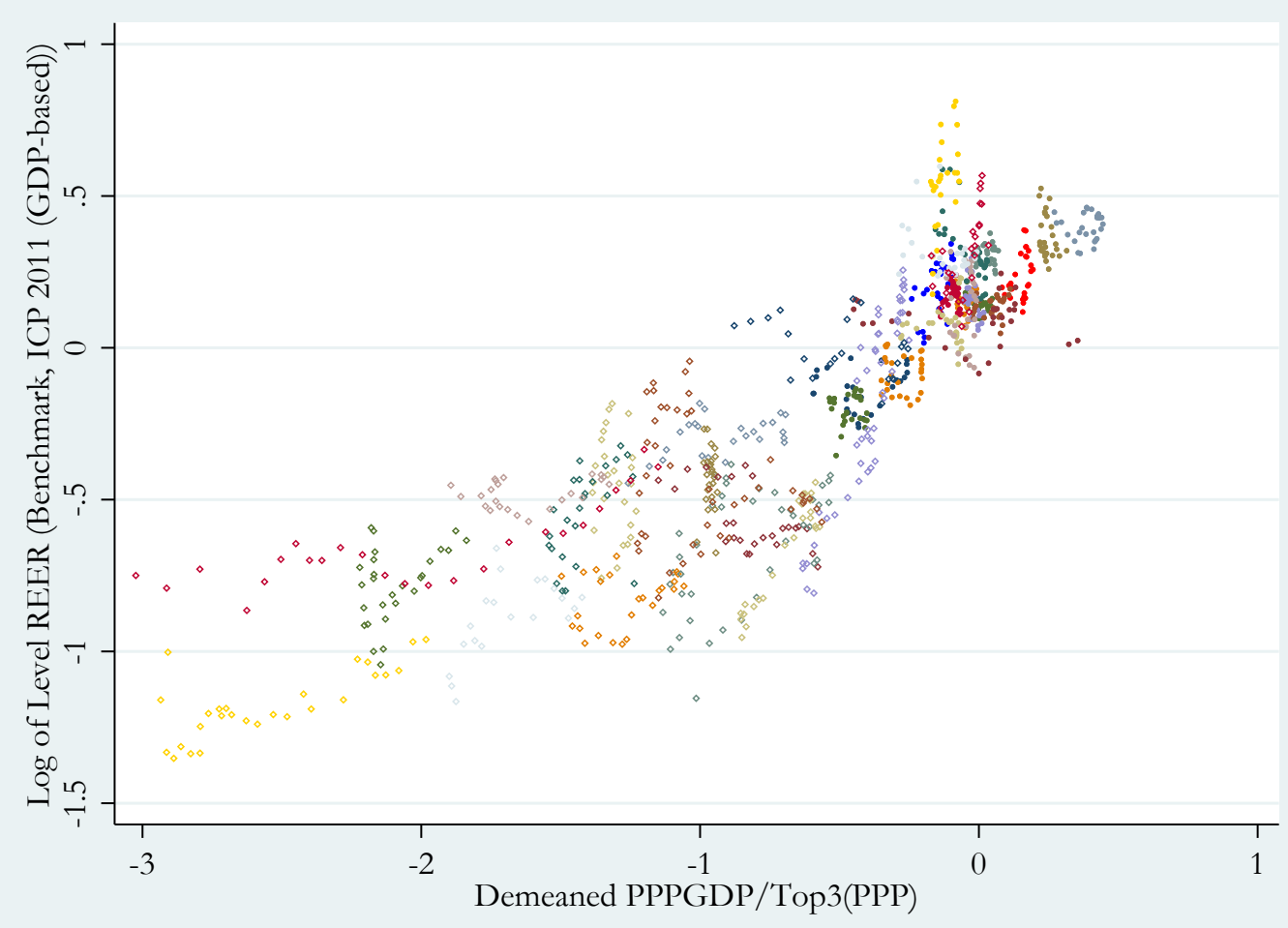


Figure 2: Log of Level REER by Country Log of Level REER

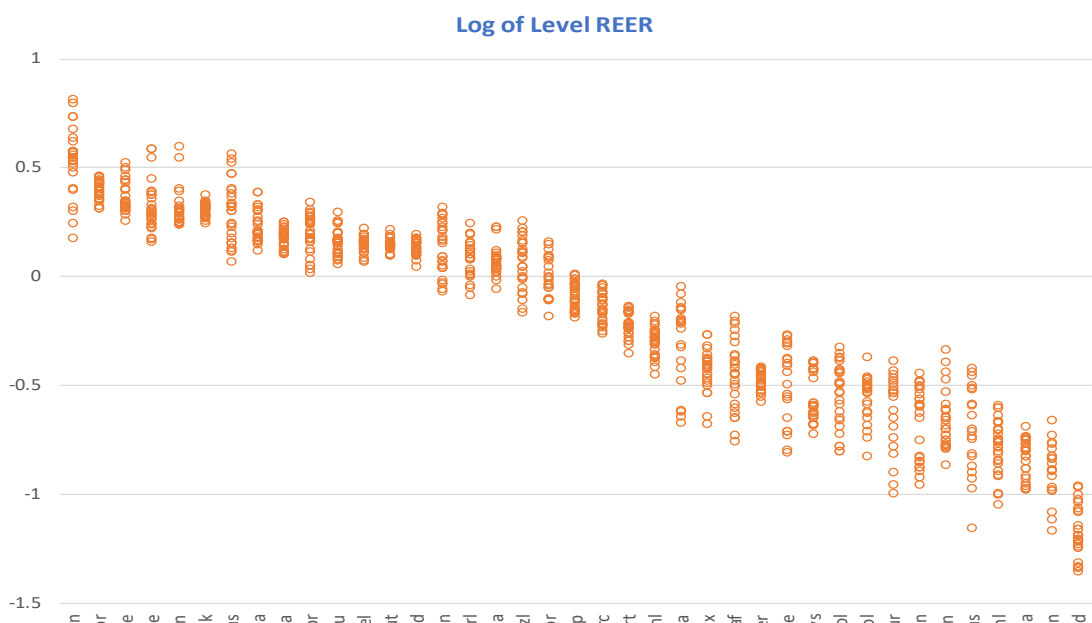

Figure 3: Log of Level REER (time series)

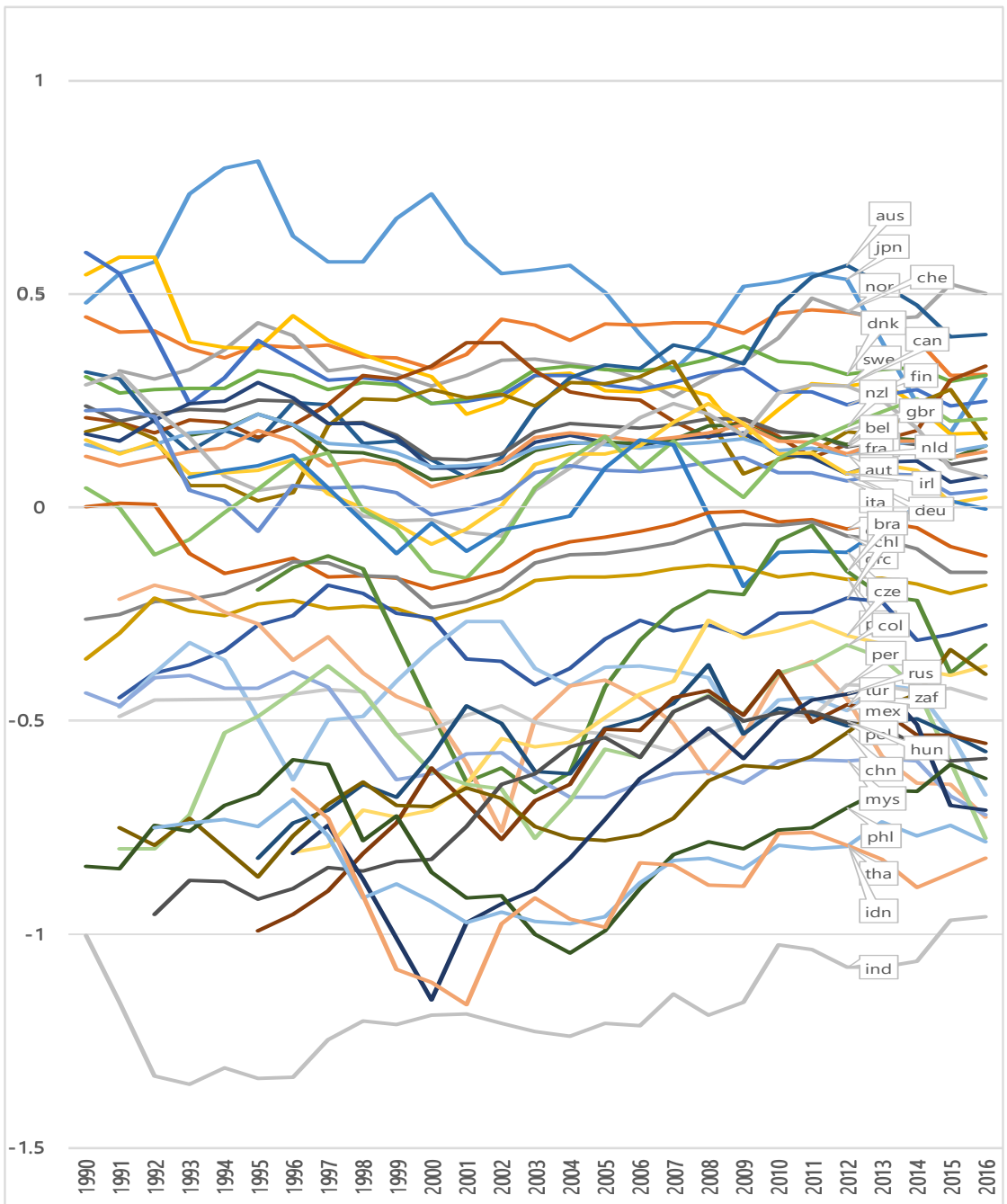


Figure 4: Benchmark Specification - Fitted Values by Country Log of Level REER - Fitted values by country

0.5

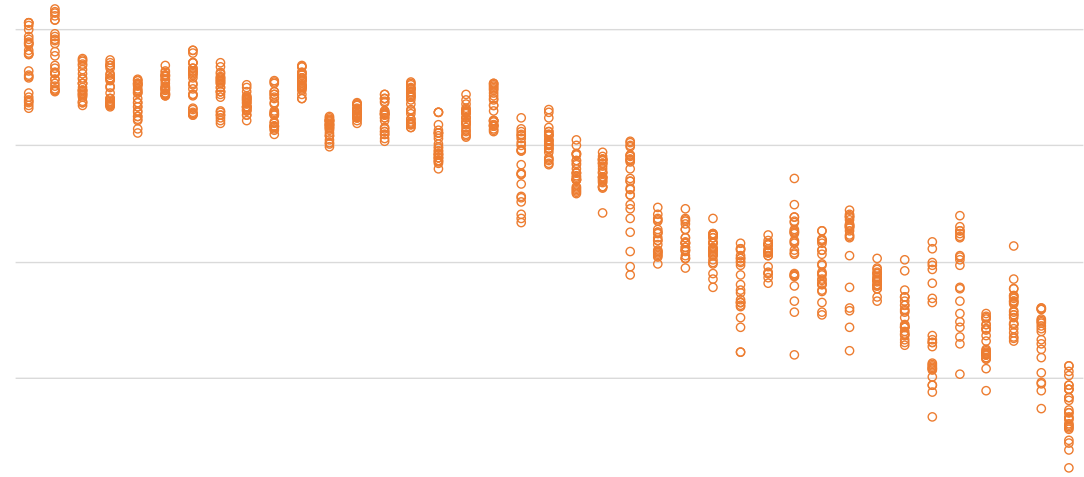

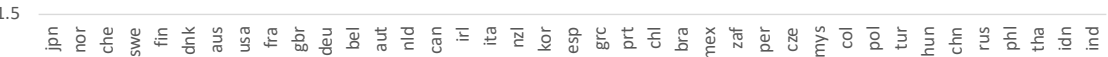

Figure 5: Benchmark Specification - Fitted Values (time series)

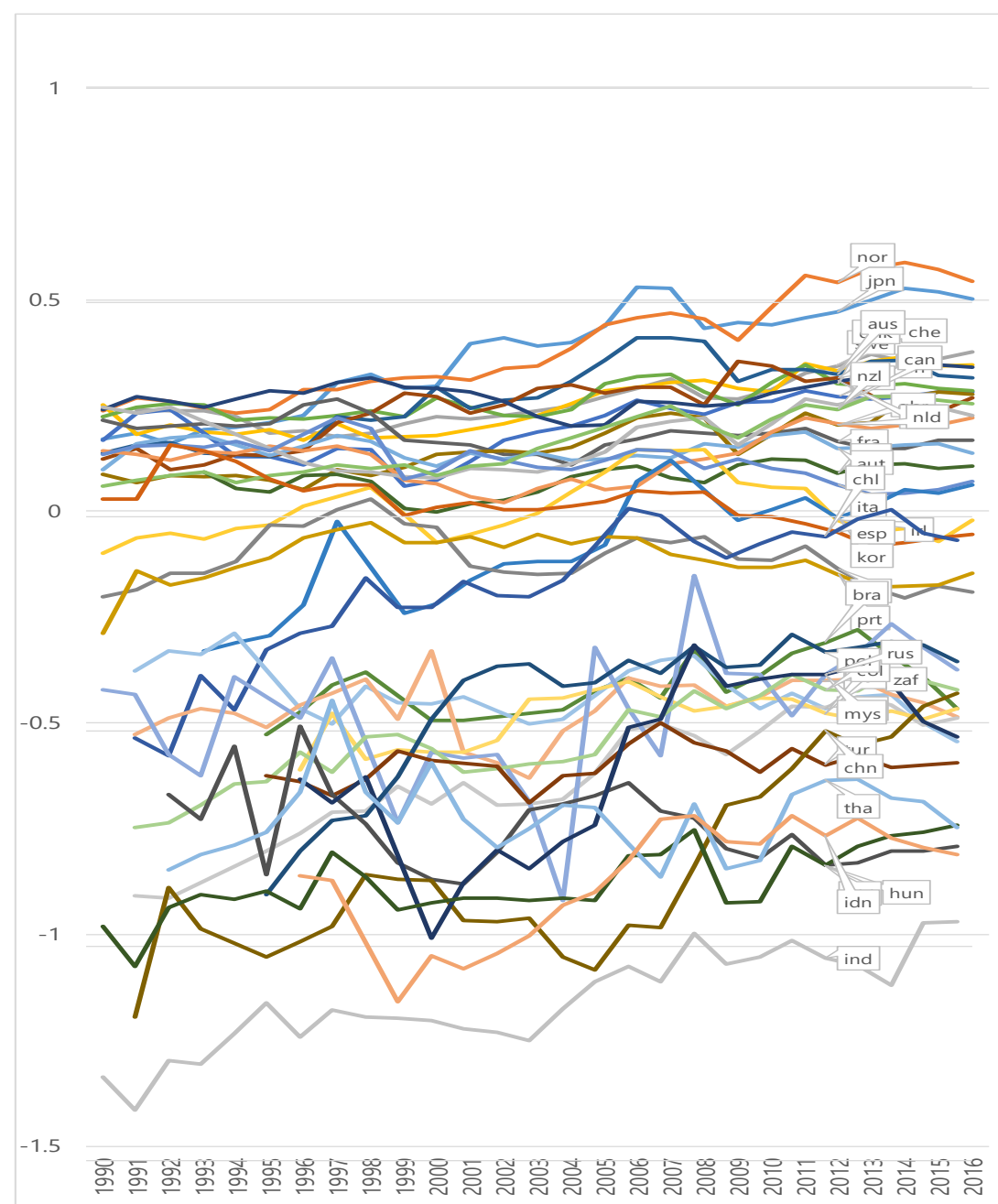

CInternational Monetary Fund. Not for Redistribution 
Figure 6: Benchmark Specification Residuals by Country

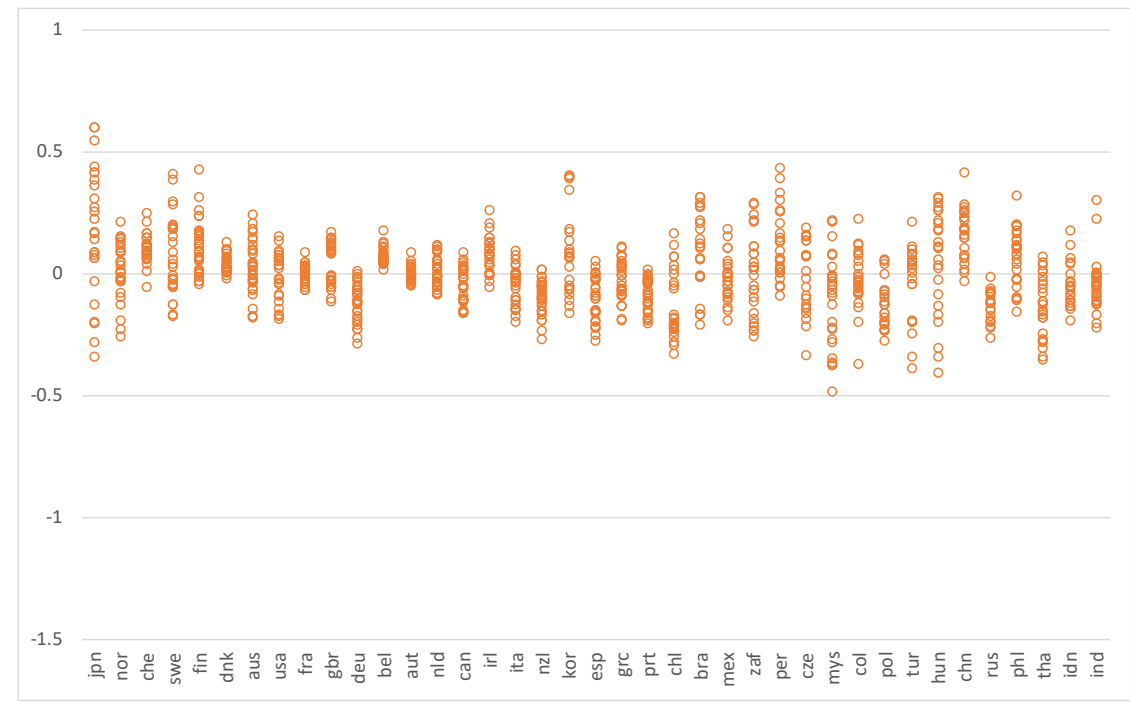

Figure 7: Benchmark Specification Residuals (time series)

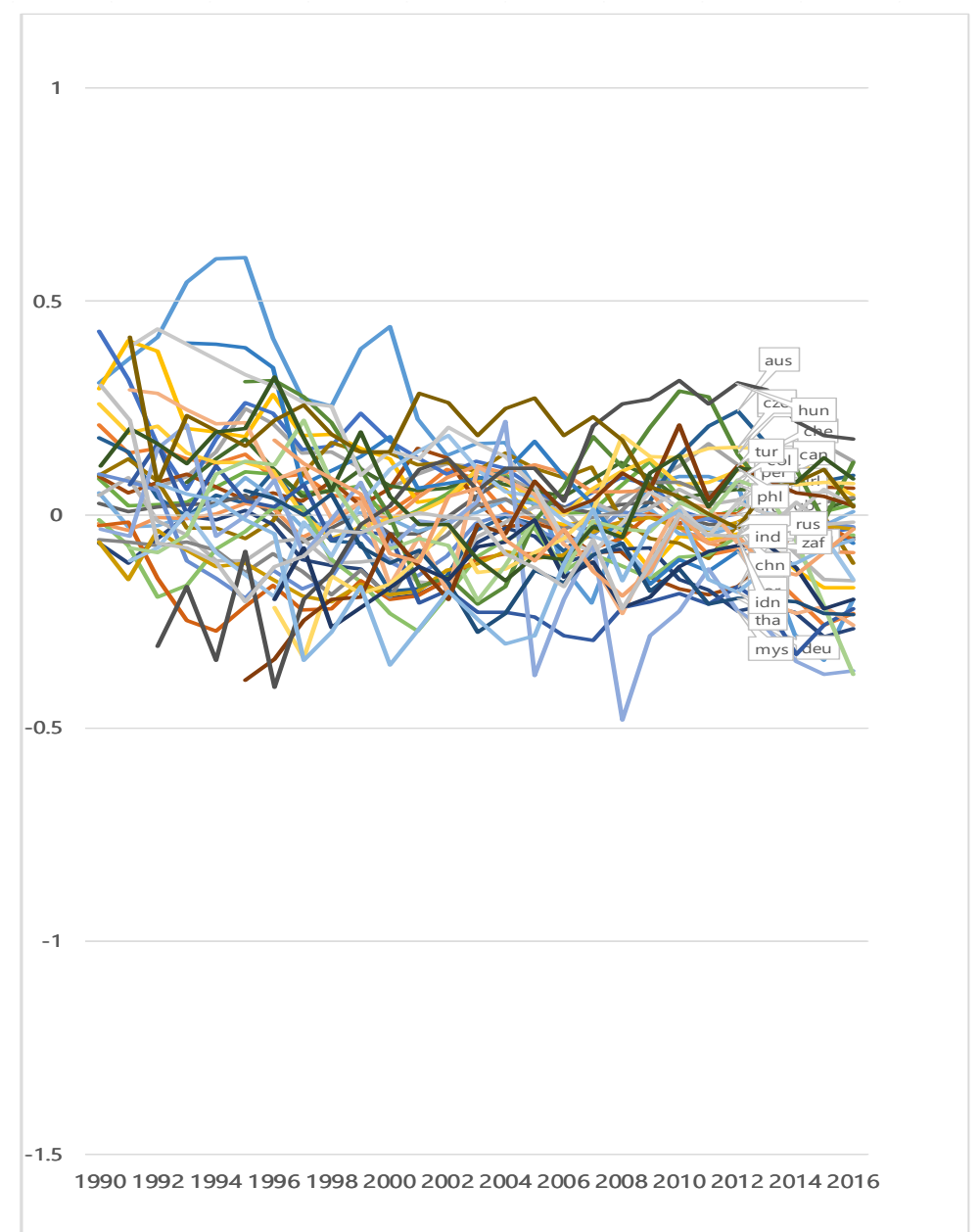

CInternational Monetary Fund. Not for Redistribution 
Figure 8. Benchmark Regression - Actual vs Fitted

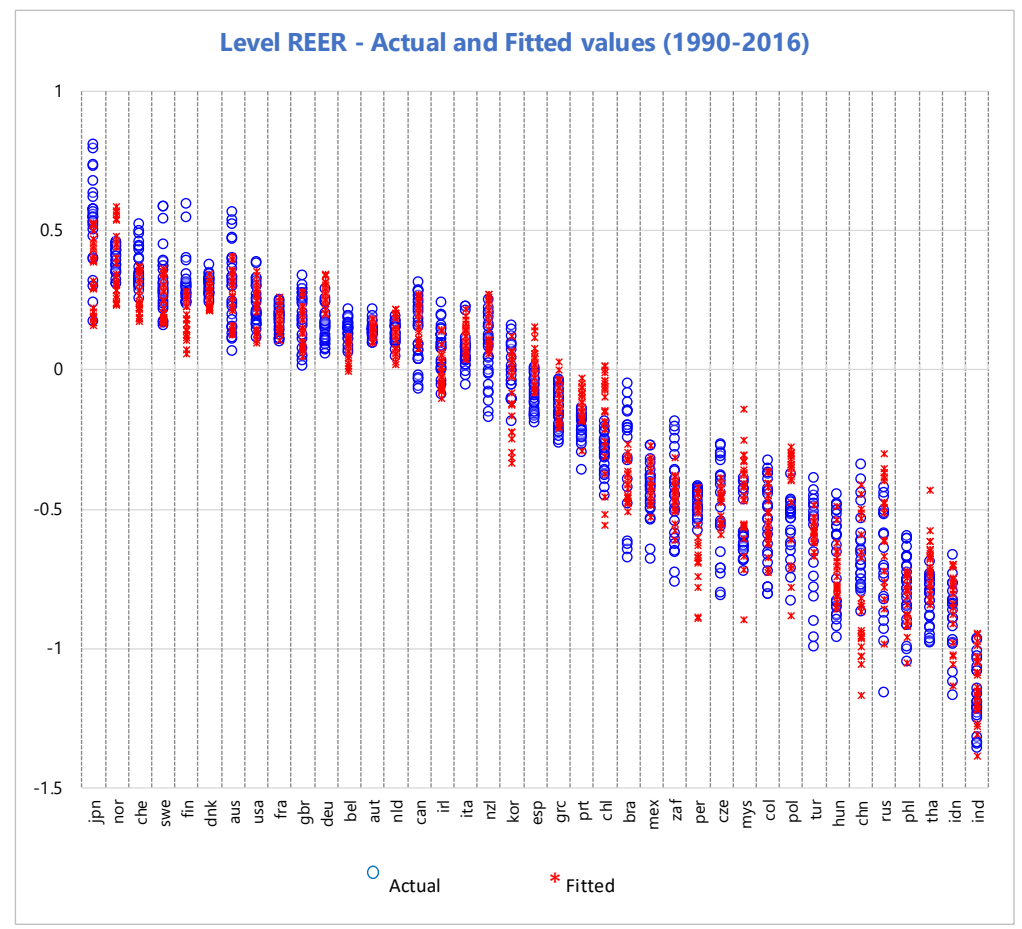

Figure 9. Cross-Country Ranking Comparison: Robustness to Different Level REERs in the Base Year

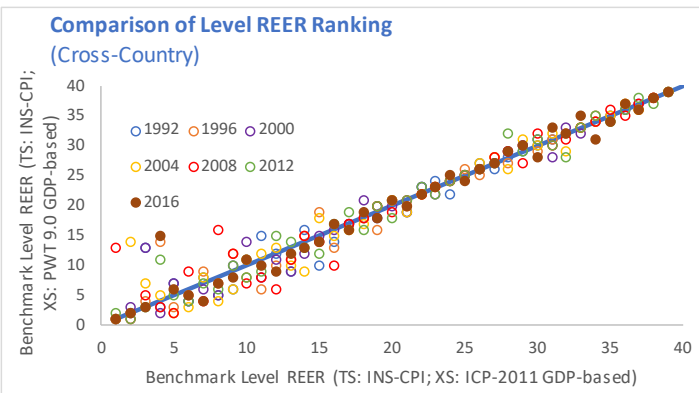

Sources: IMF staffcalculations based on INS-IMF, WEO-IMF, Penn World Ta ble and ICP-WB.
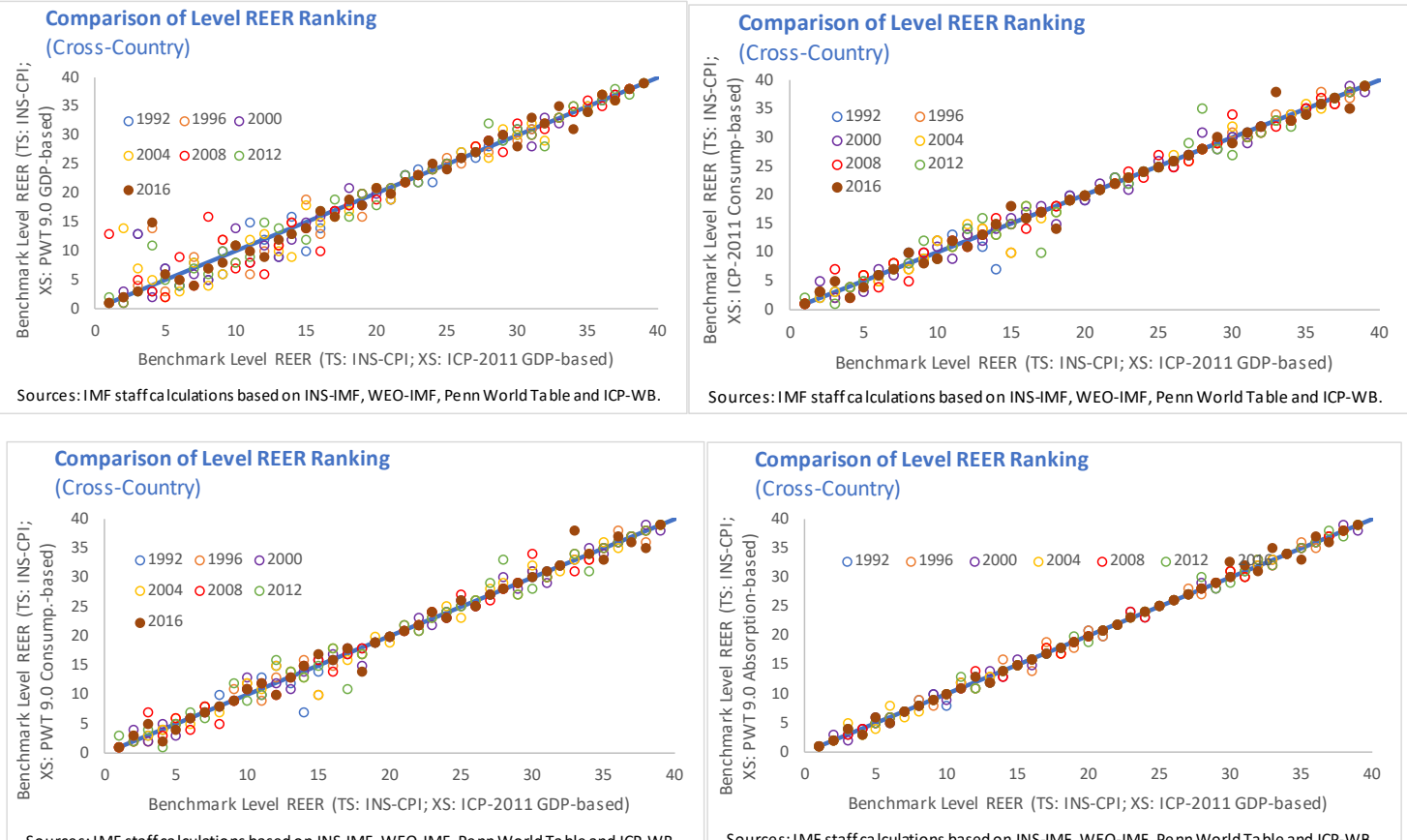

Source : IMF staff ca lculations based on INS-IMF, WEO-IMF, Penn World Ta ble and ICP-WB.

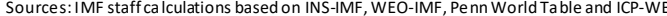


AnNex I: Alternative Reer VARIABLes

Table A1. Definitions of Alternative level of REER variables REER Index Component (time series) PPP Component (cross section, 2011)

\begin{tabular}{lll}
\hline Benchmark & IMF-INS CPI based & WB-ICP GDP-based \\
\hline Alternative 1 & IMF-INS CPI based & PWT9 GDP-based \\
\hline Alternative 2 & IMF-INS CPI based & WB-ICP Consumption-based \\
\hline Alternative 3 & IMF-INS CPI based & PWT9 Consumption-based \\
\hline Alternative 4 & IMF-INS CPI based & PWT9 Absorption-based \\
\hline Alternative 5 & $\begin{array}{l}\text { IMF-INS ER and WEO GDP } \\
\text { deflator based }\end{array}$ & WB-ICP GDP-based \\
\hline Alternative 6 & $\begin{array}{l}\text { IMF-INS ER and WEO GDP } \\
\text { deflator based }\end{array}$ & PWT9 GDP-based \\
\hline Alternative 7 & $\begin{array}{l}\text { IMF-INS ER and WEO GDP } \\
\text { deflator based }\end{array}$ & WB-ICP Consumption-based \\
\hline Alternative 8 & $\begin{array}{l}\text { IMF-INS ER and WEO GDP } \\
\text { deflator based }\end{array}$ & PWT9 Consumption-based \\
\hline Alternative 9 & $\begin{array}{l}\text { IMF-INS ER and WEO GDP } \\
\text { deflator based }\end{array}$ \\
\hline \multicolumn{2}{c}{ PWT9 Absorption-based } \\
\hline Alternative 10 & \multicolumn{1}{c}{ PWT9 GDP-based (time series] } \\
\hline Alternative 11 & \multicolumn{2}{c}{ PWT9 Absorption-based (time series] } \\
\hline Alternative 12 & \multicolumn{2}{c}{ PW }
\end{tabular}




\section{Annex II: Data Sources}

\begin{tabular}{|c|c|}
\hline Variables & Sources \\
\hline Net Foreign Assets (NFA) position & EWN: Lane and Milesi-Ferretti \\
\hline Output per worker, relative to top 3 economies & World Economic Outlook \\
\hline $\begin{array}{l}\text { Productivity-Output per worker (interacted with } \\
\text { capital openness) }\end{array}$ & World Economic Outlook and Quinn Database \\
\hline Expected Real GDP growth 5 years ahead & World Economic Outlook \\
\hline $\begin{array}{l}\text { Commodity Terms of Trade Gap (interacted with } \\
\text { trade openness) }\end{array}$ & $\begin{array}{l}\text { World Economic Outlook and World Integrated Trade } \\
\text { Solution (WITS) }\end{array}$ \\
\hline Reserve Currency Status & $\begin{array}{l}\text { Currency Composition of Official Foreign Exchange } \\
\text { Reserves (COFER) }\end{array}$ \\
\hline $\begin{array}{l}\text { Global Financial Conditions (interacted with capital } \\
\text { controls) }\end{array}$ & Haver, and Quinn Database \\
\hline $\begin{array}{l}\text { Global Financial Conditions (interacted with capital } \\
\text { controls and reserve currency) }\end{array}$ & Haver, COFER and Quinn Database \\
\hline The Old-Age Dependency Ratio (OADR) & UN World Population Prospects \\
\hline Population Growth & UN World Population Prospects \\
\hline Fiscal Policy & World Economic Outlook \\
\hline Health Spending & OECD, WDI, CEPAL, FAD, and ADB \\
\hline Foreign Exchange Intervention (FXI) & $\begin{array}{l}\text { World Economic Outlook, EWN: Lane and Milesi- } \\
\text { Ferretti, Data Template on International Reserves and } \\
\text { Foreign Currency Liquidity, and Quinn Database }\end{array}$ \\
\hline Credit Gap & $\begin{array}{l}\text { BIS (Credit statistics) and World Bank (Global } \\
\text { Financial Development Database) }\end{array}$ \\
\hline Real Effective Exchange Rate & Information Notice System (INS) \\
\hline Price Level & World Bank's International Comparison Program, 2011 \\
\hline Real Interest Rates (interacted with capital controls) & $\begin{array}{l}\text { International Financial Statistics, World Economic } \\
\text { Outlook, Haver, and Quinn Database }\end{array}$ \\
\hline Capital Stock per employed person & $\begin{array}{l}\text { Feenstra, Robert C., Robert Inklaar and Marcel P. } \\
\text { Timmer (2013), "The Next Generation of the Penn } \\
\text { World Table" }\end{array}$ \\
\hline Ratio of Traded/Non-Traded Sector Productivity & $\begin{array}{l}\text { Rui C. Mano and Marola Castillo (2015), "The Level of } \\
\text { Productivity in Traded and Non-Traded Sectors for a } \\
\text { Large Panel of Countries", and World Bank's WDI } \\
\text { Database }\end{array}$ \\
\hline Share of administered prices & $\begin{array}{l}\text { European Bank of Reconstruction and Development } \\
\text { (Structural Changes Indicators) }\end{array}$ \\
\hline
\end{tabular}




\section{Annex III: Variables Definition in the EBA Models}

Most variables included in the REER regression are measured relative to the trade-weighted average of other economies' levels. Explicit mention is made to variables that do not enter in relative terms.

- $\quad \boldsymbol{N F A - t o - G D P}$. This variable enters directly (not relative) in level terms. NFA data are an updated and extended version of the Lane and Milesi-Ferretti (2007) EWN dataset.

- Output per worker, relative to top 3 economies. Ratio of PPP GDP to working age population relative to average of Germany, Japan, and U.S., demeaned.

- Population growth. Annual growth rate of total population.

- Old age dependency ratio. Ratio of population aged over 65 divided by population between 30 and 64 years old.

- 5-year growth forecast. The IMF's WEO 5-years ahead rate of real GDP growth. This is a proxy for potential output growth, since over the medium-term cyclical factors are not expected to play a role.

- Public health spending/GDP. Public health expenditure is collected from various sources. The OECD definition includes "health expenditure and financing, current expenditure on health, government/compulsory schemes, all providers (as share of GDP)." The OECD follows System of Health Accounts (SHA) 2011 to determine the financing categories. While other data sources use similar definitions, there are differences in some cases. For example, the OECD only considers government and compulsory schemes as public expenditure, whereas WDI also includes external borrowing and NGO grants.

- Global risk aversion proxy, VXO. The VXO is an index of implied U.S. stock market volatility created by the Chicago Board Options Exchange (CBOE), and is based on the S\&P 100. It is available since 1986. It measures the same concept as the VIX, which is based on S\&P 500 and is available only since 1993. Annual average during the sample period is 0.2 . The VXO is interacted with capital account openness. Such interacted term is entered alone as well as interacted also with the respective country's share of its own currency in reported reserves held by central banks worldwide (see below).

- Own currency share in world reserves. Share of the country's own currency in total stock of world reserves proxies for the "exorbitant privilege." This share in 2017 was highest for the US dollar (67 percent), followed by the euro (20 percent), the yen (4.7 percent), and sterling ( 4.4 percent). This variable enters both alone and interacted with 
the VIX and the capital account openness index. In the baseline specification, although the variable by itself is negative $(-0.36)$, it should be interpreted together with the coefficient on the interaction, which is positive $(+0.83)$

- Commodity terms of trade. This regressor aims to capture the role of cyclical developments in commodity prices in influencing a country's overall terms of trade, by taking into account each country's commodity trade pattern structure and relative importance. The regressor is constructed in several stages. The commodity index is the ratio of a geometric weighted-average price of 43 commodity export categories to a geometric weighted-average price of 43 commodity imports, each relative to manufactured goods prices in advanced economies, where weights are given by each commodity's share in the countries' export or imports. ${ }^{10}$ This index is normalized using the 2011 value of terms of trade.

- Capital controls index. Capital controls are proxied using the Quinn index on overall capital controls on the private sector. The index is scaled and varies between 0 (no controls) and 1 (full controls). The 2017 capital controls mean across countries for 2017 was 0.16 , with values ranging between 0 and 0.75 . This variable is interacted with the VIX and real interest rates.

- Foreign exchange intervention (instrumented). FXI is measured as the change in central bank foreign exchange reserves including off-balance sheet foreign exchange intervention during the year, scaled by nominal GDP in U.S. dollars. This variable is instrumented with the difference between M2/GDP and reserves/GDP, reserve accumulation and emerging market/developing economies indicator, all interacted with capital controls index, to account for various reserve accumulation motives (the first stage regression also controls for independent regressors of the REER regression).

- Real interest rate. This variable is the difference between the nominal short-term interest rate and the annual inflation rate. The short-term interest rate is more widely and more consistently available than the policy rate, and the two indicators tend to comove very strongly given their similar maturities. The variable is demeaned and interacted with capital controls

\footnotetext{
10 To illustrate, consider a country that exports no commodities. Then the numerator will be the product of each of the 43 commodity relative price indices to the power of zero which will equal one. Conversely, if a country has a balanced trade in one commodity (say a given foodstuff variety), with exports and imports of that commodity being 20 percent of its total average trade (=(exports+imports)/2). Then country's TOT will not be affected for global relative price of that commodity as the index will deliver (Pfood/Pman)0.2/(Pfood/Pman)0.2=1, irrespective of the value of Pfood/Pman. Finally, take a country that the same food commodity accounts for 20 percent of its exports and 20 percent of its imports but overall imports are twice as large exports. Then that TOT index will be (Pfood/Pman $) 0.1 /(\mathrm{Pfood} / \mathrm{Pman}) 0.2=(\mathrm{Pfood} / \mathrm{Pman})-0.1$. Taking logs, it can be seen that the country will experience a TOT deterioration of 1 percent when the price of that commodity rises by 10 percent.
} 
- Private credit-to-GDP gap. The credit-to-GDP ratio is detrended using a one-sided Hodrick-Prescott filter to eliminate cross-country differences in the level of financial development and capture financial excesses more closely. The credit-to-GDP ratio is measured as total credit (bank and nonbank) provided to the non-financial private sector, excluding non-bank cross-border flows from the BIS. The World Bank Financial Development Database, which is used in some cases, has similar coverage.

- Institutional quality. This variable includes 12 sub-indicators from the International Country Risk Guide (ICRG) dataset: government stability; internal conflict; external conflict; military in politics; law and order; ethnic tensions; bureaucracy quality; socioeconomic conditions; investment profile; corruption; religious tensions; and democratic accountability. The indicators are drawn from surveys of risk perceptions related to each of these 12 characteristics. The values are normalized to range between 0 and 1 , with higher values signifying less risk.

- Trade openness. Average ratio of goods and services exports and imports to GDP.

- Real Effective Exchange Rate (REER) Levels. As explained in the main text, to convert the REER Index into levels, (the log of) the REER Index is rebased to the year 2011, and then the log of PPP relative prices is added. To construct the PPP relative price variable, the 2011 price level (GDP, expenditure based) of each country is rescaled such that the US price level equals 1 .

- Capital Stock per employed person. The variable is obtained by dividing capital stock at constant 2005 national prices by total employed population.

- VAT revenue. VAT revenue as a percent of GDP.

- Ratio of Traded/Non-Traded Sector Productivity. Ratio is estimated using sectoral labor productivities at 2005 USD PPP from the Mano and Castillo (2015) dataset. Missing PPP data are obtained using fitted values from an OLS regression of sectoral USD $\log (\mathrm{PPP})$ on sectoral productivity at market rates. Where values for sectoral productivities are missing, the series are extended using changes in real labor productivities from the WDI's sectoral productivity database.

- Share of administered prices. This variable is only relevant and available for a few transition economies which experienced a significant reduction in the share of administered prices during their transition towards a market economy. For most other countries, a value of zero is assigned. 


\section{Appendix: Additional Tables and Figures}

Appendix Table 1. Unit root tests

\begin{tabular}{|c|c|c|c|}
\hline \multirow[b]{2}{*}{ Variables } & \multicolumn{3}{|c|}{ REER-Level model } \\
\hline & $\begin{array}{c}\text { Fisher test } 1 / \\
\text { H0: All panels } \\
\text { have unit root } \\
\text { (Z-statistic) }\end{array}$ & $\begin{array}{c}\text { Hadri test 2/ } \\
\text { H0: All panels are } \\
\text { stationary } \\
\text { (Z-statistic) }\end{array}$ & $\begin{array}{l}\text { Unit root? } \\
\text { (diagnostic) }\end{array}$ \\
\hline REER-Level & $-2.27^{\star \star}$ & $26.31^{\star \star \star}$ & inconclusive \\
\hline Commodity terms of trade (log level, rel. TRD PTR) & 3.68 & $56.31^{* * *}$ & yes \\
\hline VIX*capital account openness (lagged) & $-5.18^{\star \star \star}$ & $1.95^{\star \star}$ & inconclusive \\
\hline VIX*capital account openness * reserve currency status (lagged) & $-4.17^{\star \star \star}$ & -3.64 & no \\
\hline Reserve currency status & 0.57 & $9.41^{\star \star \star}$ & yes \\
\hline Old age dependency ratio (rel. TRD PTR) & 5.18 & $44.62^{\star \star \star}$ & yes \\
\hline Population growth (rel. TRD PTR) & 0.06 & $44.44^{\star \star \star}$ & yes \\
\hline Output per worker (lagged, rel. top 3 economies) & 4.24 & $49.41^{\star \star \star}$ & yes \\
\hline Capital stock per employed person (lagged, rel. TRD PTR) & 0.74 & $41.87^{\star \star \star}$ & yes \\
\hline Traded/non-traded productivity (lagged, rel. TRD, PTR) & $-1.30^{\star}$ & $46.95^{\star \star \star}$ & inconclusive \\
\hline Share of administered prices & $-3.22^{* \star *}$ & -1.37 & no \\
\hline VAT revenue (\% GDP, rel. TRD PTR) & -7.25 & $29.47^{* \star *}$ & yes \\
\hline Institutional quality (rel. TRD PTR) & $-4.62^{\star \star \star}$ & $28.71^{\star \star *}$ & inconclusive \\
\hline Trade openness (lag, rel. TRD PTR) & 2.17 & $45.85^{\star \star *}$ & yes \\
\hline Expected real GDP growth 5 years ahead (rel. TRD PTR) & $-5.30^{\star \star \star}$ & $27.58^{\star \star \star}$ & inconclusive \\
\hline Net Foreign Assets(NFA) position (lagged) & 2.44 & $44.35^{\star \star *}$ & yes \\
\hline Real interest rate *capital account openness (rel. TRD PTR) & $-10.70^{\star \star \star}$ & $20.81^{\star \star \star}$ & inconclusive \\
\hline Health spending (lagged, rel. TRD PTR) & -0.49 & $38.79 * \star \star$ & yes \\
\hline FXIcapital controls (instrumented, rel. TRD PTR) & $-11.65^{\star \star \star}$ & $6.64^{\star \star \star}$ & inconclusive \\
\hline Credit gap (rel. TRD PTR) & 2.80 & $29.55^{\star \star *}$ & yes \\
\hline \multicolumn{4}{|l|}{ * $10 \%$ significance; ${ }^{* *} 5 \%$ significance; ${ }^{* * \star} 1 \%$ significance } \\
\hline \multicolumn{4}{|l|}{ rel. TRD PTR denotes "relative to trading partners". } \\
\hline \multicolumn{4}{|c|}{ 1/ Phillips-Perron test with no lags. Results are the same for the Dickey-Fuller tests. } \\
\hline 2/ Requires balanced panel. Test run for $1996-2016$ period, and & & & \\
\hline
\end{tabular}

Appendix Table 2. Cointegration tests

\begin{tabular}{|c|c|}
\hline \multicolumn{2}{|c|}{$\begin{array}{c}\text { Model residual panel unit root test 1/ } \\
\text { HO: All panels have unit roots }\end{array}$} \\
\hline $\begin{array}{l}\text { Z-statistic } \\
\text { Fisher unit root }\end{array}$ & $\begin{array}{l}\text { REER-Level } \\
\text { residual } \\
-4.10^{\star \star \star}\end{array}$ \\
\hline \multicolumn{2}{|c|}{$\begin{array}{c}\text { Cointegration pooled tests } \mathbf{2 /} \\
\text { HO: No cointegration }\end{array}$} \\
\hline t-statistic & $\begin{array}{l}\text { REER-level } \\
\text { model }\end{array}$ \\
\hline Dickey-Fuller & $-3.52^{\star \star \star}$ \\
\hline Modified Dickey-Fuller 3/ & $-3.33^{* * *}$ \\
\hline Augmented Dickey-Fuller (1 lag) 3/ & $-3.66^{* \star *}$ \\
\hline
\end{tabular}


Appendix Table 3: Sequential variable introduction based on t-stat (between estimation, truncated at 8 variables)

\begin{tabular}{|c|c|c|c|c|c|c|c|c|}
\hline VARIABLES & $\begin{array}{c}\text { (1) } \\
\text { xtreg-be }\end{array}$ & $\begin{array}{c}(2) \\
\text { xtreg-be }\end{array}$ & $\begin{array}{c}3) \\
\text { xtreg-be } \\
\end{array}$ & $\begin{array}{c}4) \\
x \text { treg-be }\end{array}$ & $\begin{array}{c}5) \\
\text { xtreg-be } \\
\end{array}$ & $\begin{array}{c}6) \\
\text { xtreg-be } \\
\end{array}$ & $\begin{array}{c}(7) \\
\text { xtreg-be }\end{array}$ & $\begin{array}{c}(8) \\
\text { xtreg-be } \\
\end{array}$ \\
\hline Lag Demeaned PPPGDP/Top3(PPP)] & $\begin{array}{c}0.54 * * * \\
(0.00)\end{array}$ & $\begin{array}{c}0.53^{* * *} \\
(0.00)\end{array}$ & $\begin{array}{c}0.37^{* * *} \\
(0.00)\end{array}$ & $\begin{array}{c}0.28^{* * *} \\
(0.00)\end{array}$ & $\begin{array}{c}0.29 * * * \\
(0.00)\end{array}$ & $\begin{array}{c}0.27^{* * *} \\
(0.00)\end{array}$ & $\begin{array}{c}0.14 \\
(0.15)\end{array}$ & $\begin{array}{c}0.12 \\
(0.18)\end{array}$ \\
\hline Share of administered prices in CPI & & $\begin{array}{c}-3.75^{* * *} \\
(0.00)\end{array}$ & $\begin{array}{c}-3.48^{* * *} \\
(0.00)\end{array}$ & $\begin{array}{c}-3.27^{* * *} \\
(0.00)\end{array}$ & $\begin{array}{c}-3.00 * * * \\
(0.00)\end{array}$ & $\begin{array}{c}-2.76 * * * \\
(0.00)\end{array}$ & $\begin{array}{c}-2.81^{* * *} \\
(0.00)\end{array}$ & $\begin{array}{c}-3.03^{* * *} \\
(0.00)\end{array}$ \\
\hline Lag of Public health exp. (The new series) (rel to TRD PRT) & & & $\begin{array}{c}7.52^{* * *} \\
(0.00)\end{array}$ & $\begin{array}{c}6.42^{* * *} \\
(0.01)\end{array}$ & $\begin{array}{l}4.15^{*} \\
(0.07)\end{array}$ & $\begin{array}{l}4.00^{*} \\
(0.07)\end{array}$ & $\begin{array}{l}3.59 * \\
(0.09)\end{array}$ & $\begin{array}{c}4.50^{* *} \\
(0.03)\end{array}$ \\
\hline ICRG-12 (rel to TRD PRT) & & & & $\begin{array}{l}1.05^{* *} \\
(0.02)\end{array}$ & $\begin{array}{c}1.43^{* * *} \\
(0.00)\end{array}$ & $\begin{array}{c}1.48^{* * *} \\
(0.00)\end{array}$ & $\begin{array}{c}1.54 * * * \\
(0.00)\end{array}$ & $\begin{array}{c}1.47^{* * *} \\
(0.00)\end{array}$ \\
\hline Lag of Trade Openness (avg. of exports and imports to GDP) (rel to TRD PRT) & & & & & $\begin{array}{c}-0.32 * * \\
(0.01)\end{array}$ & $\begin{array}{c}-0.34 * * * \\
(0.01)\end{array}$ & $\begin{array}{c}-0.33^{* * *} \\
(0.00)\end{array}$ & $\begin{array}{c}-0.35 * * * \\
(0.00)\end{array}$ \\
\hline NFA/GDP & & & & & & $\begin{array}{l}0.12^{* *} \\
(0.04)\end{array}$ & $\begin{array}{l}0.13^{* *} \\
(0.02)\end{array}$ & $\begin{array}{l}0.11^{* *} \\
(0.03)\end{array}$ \\
\hline Lag Capital stock per emplyed person at current PPPs (2005US\$) (rel to TRD PRT) & & & & & & & $\begin{array}{l}0.13^{*} \\
(0.07)\end{array}$ & $\begin{array}{l}0.16 * * \\
(0.02)\end{array}$ \\
\hline Share of the country's currency held as FX reserve by central banks worldwide & & & & & & & & $\begin{array}{c}-0.38^{* *} \\
(0.03)\end{array}$ \\
\hline Constant & $\begin{array}{c}0.16^{* * *} \\
(0.00)\end{array}$ & $\begin{array}{c}0.20^{* * *} \\
(0.00)\end{array}$ & $\begin{array}{c}0.19 * * * \\
(0.00)\end{array}$ & $\begin{array}{c}0.15^{* * *} \\
(0.00)\end{array}$ & $\begin{array}{c}0.17^{* * *} \\
(0.00)\end{array}$ & $\begin{array}{c}0.18^{* * *} \\
(0.00)\end{array}$ & $\begin{array}{c}0.15^{* * *} \\
(0.00)\end{array}$ & $\begin{array}{c}0.19 * * * \\
(0.00)\end{array}$ \\
\hline Observations & 990 & 990 & 990 & 990 & 990 & 990 & 990 & 990 \\
\hline R-squared & 0.79 & 0.89 & 0.91 & 0.93 & 0.94 & 0.95 & 0.95 & 0.96 \\
\hline Number of ifs_code & 39 & 39 & 39 & 39 & 39 & 39 & 39 & 39 \\
\hline RMSE & 0.2012 & 0.1515 & 0.1349 & 0.1265 & 0.1165 & 0.1104 & 0.1064 & 0.09985 \\
\hline
\end{tabular}

pval in parentheses

$* * * p<0.01, * * p<0.05, * p<0.1$ 
Appendix Figure 1. Cross-Country Ranking Comparison: Robustness to Using GDPdeflator For the Time Series of Level REERs
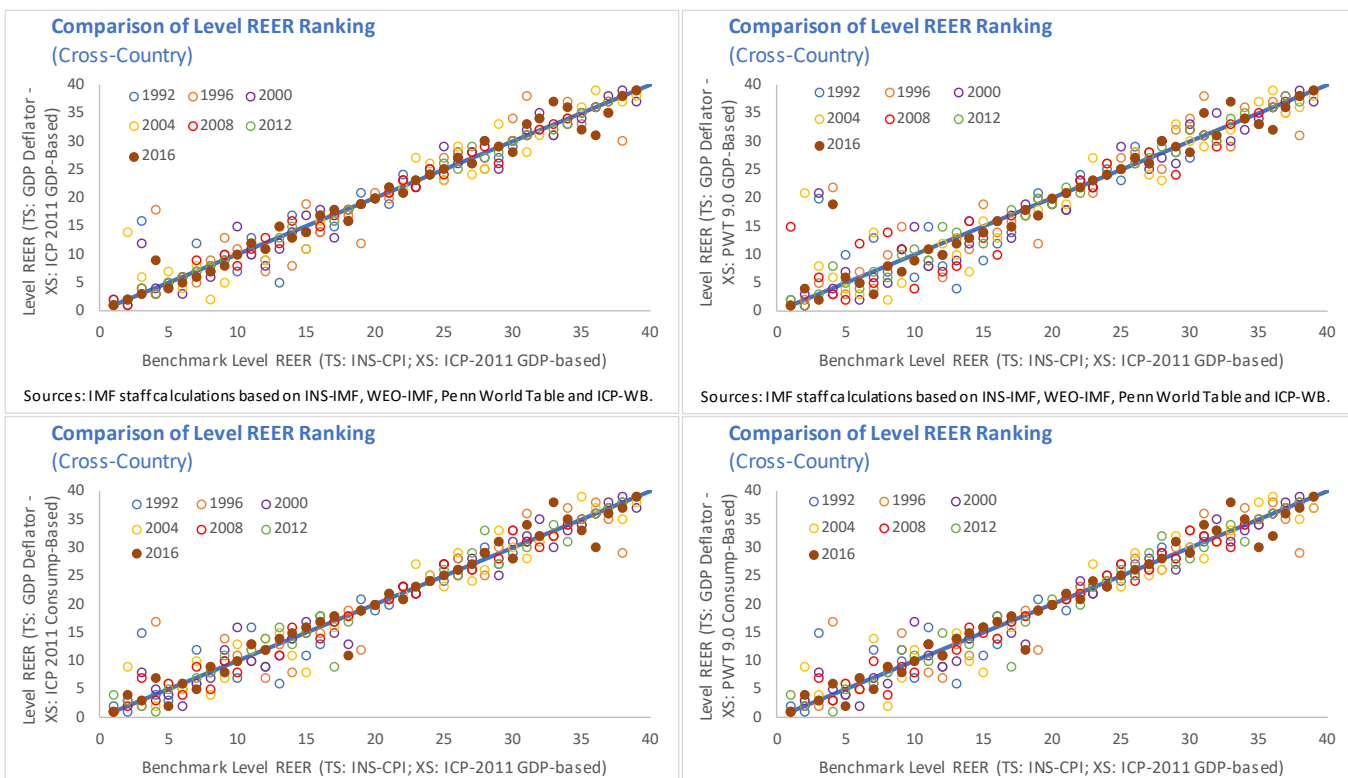

Sources: IMF staff calculations based on INS-IMF, WEO-IMF, Penn World Table and ICP-WB.

Comparison of Level REER Ranking

(Cross-Country)

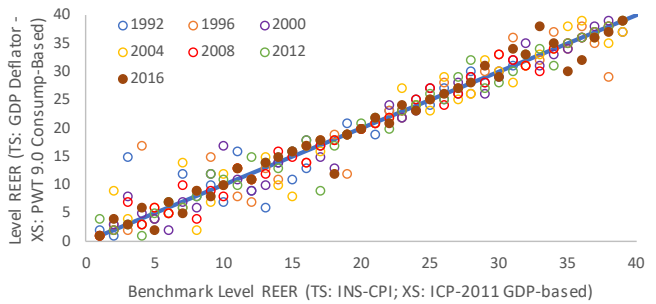

Sources: IMF staff calculations based on INS-IMF, WEO-IMF, Penn World Ta ble and ICP-WB.

Source : IMF staff calculations based on INS-IMF, WEO-IMF, Penn World Ta ble and ICP-WB.

Comparison of Level REER Ranking

(Cross-Country)

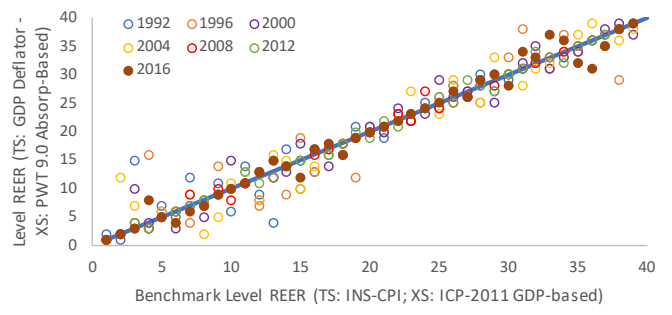

Sources: IMF staffcalculations based on INS-IMF, WEO-IMF, Penn World Ta ble and ICP-WB.

Appendix Figure 2. Comparing the Change Over Time of GDP-deflator-based and CPI-based Measures of the REER

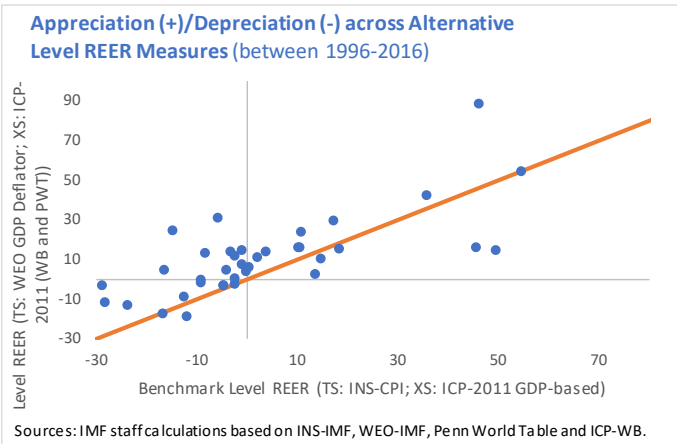

CInternational Monetary Fund. Not for Redistribution 
Appendix Figure 3. Cross-Country Ranking Comparison: Robustness to Different Level REERs in the Base Year and in the Time-Series

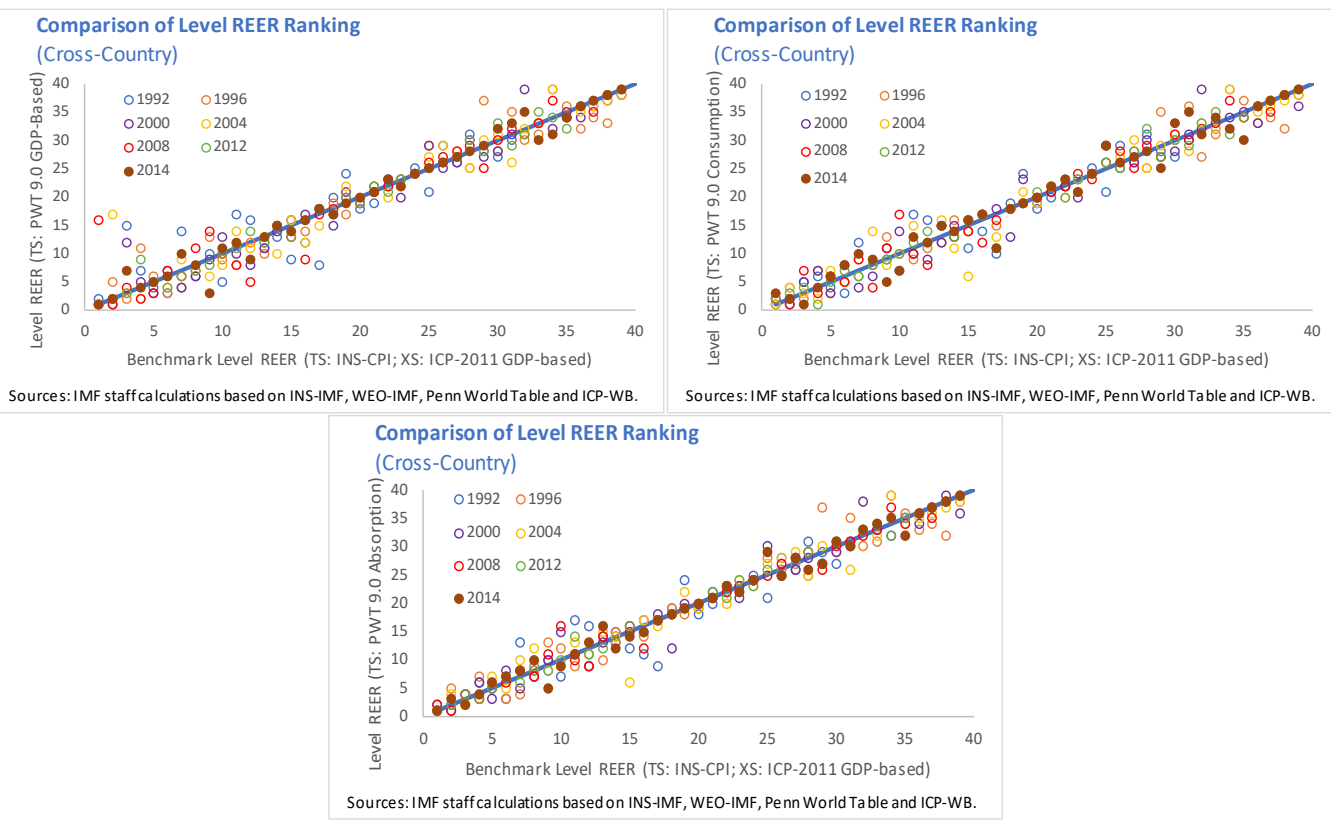

Appendix Figure 4. Level REER Appreciation/Depreciation Between Different Measures
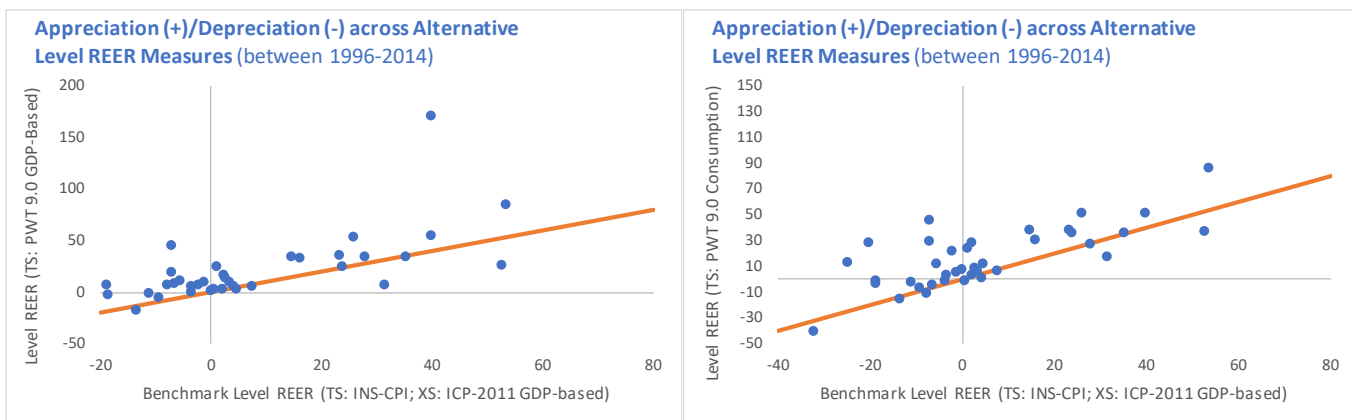

Sources: IMF staff calculations based on INS-IMF, WEO-IMF, Penn World Ta ble and ICP-WB.

Sources: IMF staffcalculations based on INS-IMF, WEO-IMF, Penn World Ta ble and ICP-WB.

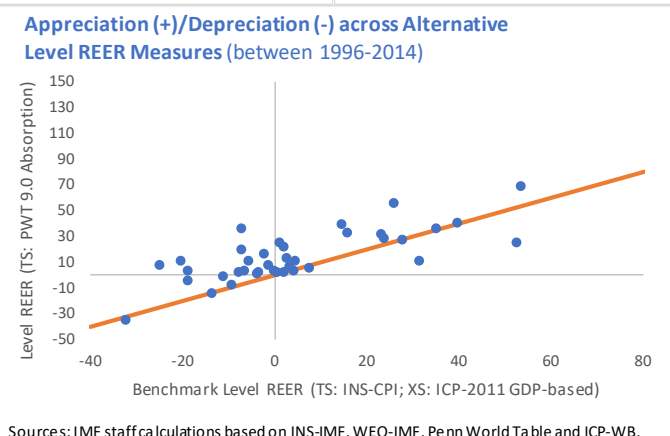

Sources: IMF staff calculations based on INS-IMF, WEO-IMF, Penn World Ta ble and ICP-WB. 